\title{
ARTICLE
}

\section{BEHAVIORAL INTERNATIONAL LAW}

\section{TOMER BROUDE ${ }^{\dagger}$}

Economic analysis and rational choice have made significant inroads into the study of international law and institutions in the last decade, relying upon standard assumptions of perfect rationality of states and decisionmakers. This approach is inadequate, both empirically and in its tendency toward outdated formulations of political theory. This Article presents an alternative behavioral approach that provides new hypotheses addressing problems in international law while introducing empirically grounded concepts of real, observed rationality. First, I address methodological objections to behavioral analysis of international law: the focus of behavioral research on the individual, the empirical foundations of behavioral economics, and behavioral analysis's relative lack of parsimony. I then offer indicative behavioral research frameworks for three contemporary puzzles in international law: (a) the relative inefficiency of the development of international law, (b) dissent in international tribunals, and (c) target selection in armed conflict. Behavioral research in international law can serve as a viable, enriching alternative and complement to conventional economic analysis, so long as it is pursued with academic and empirical rigor as well as intellectual humility.

† Sylvan M. Cohen Chair in Law and Vice-Dean, Faculty of Law and Department of International Relations, Hebrew University of Jerusalem. Both slow and fast thinking have affected the development of this Article. The ideas in it were first presented at the Annual Meeting of the Public Choice Society, New Orleans (Mar. 2005), and subsequently at the ESILASIL Research Forum, Changing Futures? Science and International Law, Helsinki (Oct. 2009), at Università Commerciale Luigi Bocconi, Milano (Nov. 2009), and at the Minerva Center for Human Rights conference on Proportionality in Armed Conflicts, Jerusalem (Nov. 2010). I have benefited greatly from exchanges with Anne van Aaken, Marc Busch, Shai Dothan, Jeffrey Dunoff, Manfred Elsig, James Flett, Jean Galbraith, Ehud Guttel, Yoram Haftel, Larry Helfer, Moshe Hirsch, Friedrich Kratochwil, Andrew Lang, Meredith Kolsky Lewis, Lauge Poulsen, Giorgio Sacerdoti, Greg Shaffer, Yuval Shany, Joel Trachtman, David Victor, and Eyal Zamir. Yael Rimer-Cohen and Vera Shikhelman provided exceptional research assistance in the earliest stages. Thanks also to the Milton and Miriam Handler Foundation for its financial support. 
INTRODUCTION: A NEW AND NECESSARY AGENDA ..............................1100

I. REVISITING THE LIMITS OF RATIONAL CHOICE AND

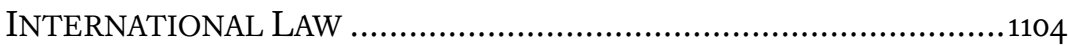

II. WHY BEHAVIORAL INTERNATIONAL LAW? .................................... 1112

III. OBJECTIONS TO BEHAVIORAL INTERNATIONAL LAW AND

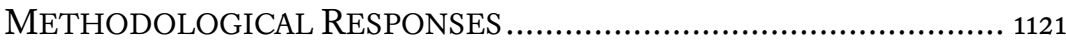

A. The Individual Focus of Behavioral Theory .................................. 1121

1. The State as a Unitary Actor? ...........................................1122

2. Decisionmaking Collectives in International Law ................1126

3. The Individual as a Subject and Decisionmaker in

International Law ..........................................................1129

B. The Empirical Foundations of Behavioral Theory ............................1130

1. Theoretical Applications ..................................................1132

2. Experimental Research ............................................... 1133

3. Field Studies....................................................................1134

C. The Parsimony of Traditional Concepts of State Rationality............... 1135

IV. SOME INDICATIVE APPLICATIONS OF BEHAVIORAL RESEARCH

TO INTERNATIONAL LEGAL ISSUES.............................................1136

A. The State Level: The Efficiency of International Law-Making and the Status Quo Bias.

B. Small Decisionmaking Groups: Judicial Design and Conformity Effects in International Tribunals.... 1143

C. The Individual: Target Selection, Framing Effects and Preference Reversals in International Humanitarian Law.............................. 1150

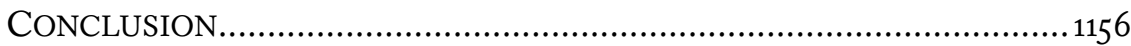

\section{INTRODUCTION: A NEW AND NECESSARY AGENDA}

How can insights from cognitive psychology and behavioral economics be meaningfully applied to international legal issues, in all their normative and prescriptive dimensions? To understand the importance and potential impact of this question, consider the following three contemporary puzzles, each relating to different dimensions of international law.

First, when-and why-does international law fail to develop, even when it is most needed? For four decades, global warming has been proclaimed the most severe crisis humanity has ever faced that can only be tackled through concerted international agreement and action. Nevertheless, concrete and effective international norms, whether 
customary or treaty-based, fail to materialize. ${ }^{1}$ Similarly, the rise of non-state actors and transnational terrorism as well as new technologies of warfare and intelligence have significantly altered the battlefield at home and abroad, dramatically so since $9 / 11$. Yet the applicable international law remains a series of treaties (and their acceptance as customary law) whose roots date back to the nineteenth century and whose latest editions are from the 1970 s. $^{2}$ This is not to say that international law in these fields has not adapted or developed at all, but why has it been so sluggish in these areas of paramount concern when it has demonstrated the capacity to develop quite meteorically with respect to other issues? $?^{3}$

Second, how should international courts be structured? In the last two decades, there has been a momentous increase in the number and influence of international courts and tribunals dealing with issues as varied as international crimes and international trade. The structure of these courts varies, as do their respective records of quality and effectiveness. ${ }^{4}$ Procedurally, some international courts allow dissenting opinions of judges, while others require a high degree of consensus among judicial decisionmakers coming from very different backgrounds. How have these differences affected judicial outcomes? Do collegial international courts

\footnotetext{
${ }^{1}$ For one account of this gap, see Tomer Broude, Warming to Crisis: The Climate Change Law of Unintended Opportunity, 44 NETH. Y.B. INT'L L. 111, 126 (2013), which offers a perspective on the limiting effects the crisis framing of global warming has had on the development of international law.

${ }^{2}$ For overt struggles with this dissonance, see generally NEW BATTLEFIELDS, OLD LAW: CRiticAl DEbates ON AsYMmetrical WARFARE (William C. Banks ed., 2011), and International Conference, New Technologies, Old Law: Applying International Humanitarian Law in a New Technological Age, HEBREW U. JERUSALEM (2011), available at http://law.huji.ac.il/eng/ merkazim.asp?cat $=2355 \&$ in $=2229$, which explore the challenges to international humanitarian law posed by non-state armed groups' ability to exploit the shortcomings of stagnant legal frameworks.

${ }^{3}$ For example, the right to self-determination would have been virtually incomprehensible to international lawyers in the late 1940s, but only twenty years later it had been elevated to the highest degree of international normativity. See SAMUEL MOYn, THE LAST UTOPIA: Human RIGHTS IN HISTORY 178-79 (2010) (describing the years following World War II as "a breakthrough period for human rights ... [that] led international lawyers to reevaluate their longconfirmed positions" on the right to self-determination). In other areas, commentators have argued that customary law can be created almost instantly through formally non-binding resolutions of international institutions. See, e.g., Bin Cheng, United Nations Resolutions on Outer Space: “Instant" International Customary Law?, 5 INDIAN J. INT'L L. 23, 24-25 (1965) (providing an example of an international guidance resolution that was treated as binding).

${ }^{4}$ See Yuval Shany, No Longer a Weak Department of Power? Reflections on the Emergence of a New International Judiciary, 20 EUR. J. INT'L L. 73, 79-80 (2009) (comparing new international courts to the International Court of Justice and the Permanent Court of International Justice).
} 
stifle the development of international law? Or do fragmented benches hinder it? ${ }^{5}$

Third, how should military attacks be conducted? Under international humanitarian law, military commanders contemplating an armed attack must follow a principle of proportionality, comparing the potential damage to non-combatants with the military advantage gained from the attack. What does this mean when viewed ex ante? How do reasonable, good faith military commanders understand and execute this norm in practice? And conversely, how should this practice affect the norm? ${ }^{6}$

Responses to all three questions, however different they may be from each other, must rely on certain understandings, fundamentally descriptive but often normative, of the ways in which states and other actors interacting with international law (e.g., diplomats, judicial decisionmakers in international tribunals, and military commanders) are expected to behave. Over the last decade, many compelling analyses of similar questions in international law have built on particular assumptions of what may be termed "perfect" rationality: the growing area of economic analysis of international law. ${ }^{7}$ In many other areas of law, however, the value of applying rational choice theory to legal questions has been questioned and contested by empirically grounded streams of behavioral economics and cognitive psychology that focus on systematic divergences from perfect rationality. ${ }^{8}$ Should these behavioral insights not now be avidly applied to international law?

\footnotetext{
${ }^{5}$ See Meredith Kolsky Lewis, Dissent as Dialectic: Horizontal and Vertical Disagreement in WTO Dispute Settlement, 48 STAN. J. INT'L L. 1, 5 (2012) (arguing that " $\mathrm{t}]$ oo much dissent can undermine the legitimacy of a court").

${ }^{6}$ See Aaron Fellmeth, The Proportionality Principle in Operation: Methodological Limitations of Empirical Research and the Need for Transparency, 45 ISR. L. REV. 125, 133-35 (2012) (offering the International Committee of the Red Cross study as an example of the divergence between "law on the books' and 'law in action'" and illustrating the impact that the proportionality principle has had on state attitudes).

${ }^{7}$ Any bibliographical list would risk injury by omission. For a literature survey likening states to individual rational actors, and hence treaties to contracts, see Alan O. Sykes, International Law, in 1 HANDBOOK OF LAW AND ECONOMICS 757, 771 (A. Mitchell Polinsky \& Steven Shavell eds., 2007). Important examples can be found in Symposium, Rational Choice and International Law, $3^{1}$ J. Legal STUD. S1 (2002), and in Symposium, Public International Law and Economics, 2008 U. ILL. L. REV. 1. Central treatises on the topic are JACK L. GOLDSMITH \& ERIC A. POSNER, THE LIMITS OF INTERNATIONAL LAW (2005); ANDREW T. GUZMAN, HOW INTERNATIONAL LAW WORKS: A RATIONAL CHOICE THEORY (2008); ERIC A. POSNER \& AlAN O. SyKes, ECONOMIC FOUNDATIONS OF INTERNATIONAL LAW (2013); and JOEL P. TRACHTMAN, THE ECONOMIC STRUCTURE OF INTERNATIONAL LAW (2008).

${ }^{8}$ See Russell B. Korobkin \& Thomas S. Ulen, Law and Behavioral Science: Removing the Rationality Assumption from Law and Economics, 88 CALIF. L. REV. 1051, 1055 (2000) ("[I]ndividuals frequently act in ways that are incompatible with the assumptions of rational choice theory.").
} 
Employed properly, a behavioral approach can contribute to international legal research by raising interesting hypotheses relating to problems in international law, and by providing frameworks for experimental and empirical testing of these hypotheses, with both explanatory and normative implications. A behavioral approach could be seen as either augmenting or in some cases supplanting the now common (one is almost tempted to say "traditional") economic analyses of international law. Indeed, in some cases, behavioral research can be useful without any recourse to the framework of economic analysis. In any event, behavioral analysis must be added to the international legal research toolbox of alternative research methodologies, each of which should be employed where it is illuminating and can be pursued with intellectual honesty.

In making the case for behavioral analysis of international law, the Article proceeds as follows. In Part I, I discuss some weaknesses of rational choice and economic analysis of international law, primarily the limits of assumptions of perfect rationality that are not backed by empirical substantiation. In Part II, I briefly explain the corrective impact of cognitive psychology on the economic analysis of law in general: its understanding that human rationality is bounded, characterized by systematic failures, shortcuts, and susceptibility to seemingly irrational traits such as fairness, but also its descriptive and empirical strengths. This is not to say that behavioral analysis is contrary to standard rational choice but rather a complement and supplement. Part II also suggests what value cognitive psychology might contribute to international legal research, highlighting how few studies currently exist in this direction. In Part III, I discuss and provide responses to what appear to be the central methodological objections to the behavioral approach to international law: (i) the focus of behavioral analysis on the individual, (ii) the empirical foundations of behavioral economics, and (iii) its relative lack of parsimony. Part IV offers indicative behavioral research frameworks for three issues in international law: (i) the development of international treaty law, (ii) the collegiality and dissent in international tribunals, and (iii) the target selection in armed conflict. Finally, I recapitulate and offer some concluding remarks on the potential role and viability of a behavioral approach to international law. 


\section{REVISITING THE LIMITS OF RATIONAL CHOICE AND INTERNATIONAL LAW}

Are states and other international legal actors "rational" when they interact with each other in the processes of making international law, abiding by it, violating it, and enforcing it? A burgeoning, essential, and predominantly American' literature that uses rational choice tools in the analysis of international law assumes that they are. ${ }^{10}$ The "law and economics" (L\&E) of international law has in the last decade made significant inroads into the study of international law. It principally rests upon assumptions of perfect rationality, whether of states or of decisionmakers, that are determinative of state conduct in international law.

To be sure, social scientists engaged in the study of international relations (IR) have used the same assumptions of rationality and employed similar methods for more than half a century. ${ }^{11}$ For most of this time, mainstream international legal scholarship has occupied the separate methodological universes of doctrinaire positivism-"natural" law

\footnotetext{
${ }^{9}$ The 2006 symposium on Public International Law and Economics held by the Max Planck Institute for Research on Collective Goods in Bonn is illuminating in this respect: all paperpresenters were from U.S. law schools, while the largely skeptical commentators were German; the symposium contributions were subsequently published in a U.S. law journal. See Georg Nolte, Public International Law and Economics: Concluding Remarks to the Bonn Conference, 2008 U. ILL. L. REV. 429. Indeed, the gap between American and European acceptance of economic analysis of law was a subject of debate at the symposium. See id. at 429 ("[E]conomic analysis of law plays a less prominent role in Europe than in the United States.").

${ }^{10}$ Assumptions as theoretical tools should not, however, be mistaken for claims about reality. The old saw about economists stuck in a hole in the ground and assuming a ladder in order to extract themselves amply demonstrates the difference. Nevertheless, both proponents and opponents of rational choice too often blur this distinction. For a further analysis on the issue, see infra text accompanying notes 33-34.

${ }^{11}$ The "realist" school that launched the disciplinary study of IR in the late 1940 s in a Hobbesian tradition employed rudimentary concepts of rational choice by emphasizing the role of national interest in the determination of state behavior and state sensitivity to incentives presented by power relations. See HAns J. Morgenthau, Politics AmOng Nations: The STRUGGLE FOR POWER AND PEACE 3-17 (6th ed. 1985) (discussing the developments of the realist school of international politics). Neoliberal IR theory built on the rationality of states and added layers of strategic thinking to state behavior through the use of game theory. See, e.g., Duncan Snidal, The Game Theory of International Politics (attributing the increasing popularity of game theory to its application to international law), in COOPERATION UNDER ANARCHY 25, 25 (Kenneth A. Oye ed., 1986); see also James D. Morrow, Modeling the Forms of International Cooperation: Distribution Versus Information, 48 INT'L ORG. 387, 388-89 (1994) (demonstrating how game theory can help resolve the problems of sanctioning, monitoring, distribution, and information commonly faced in international relations); Duncan Snidal, Coordination Versus Prisoners' Dilemma: Implications for International Cooperation and Regimes, 79 AM. POL. SCI. REV. 923, 923-24 (1985) (classifying the challenges faced by international relations as collective-action problems that can be explained through the application of game theory).
} 
idealization or intuitive "policy-oriented" prescriptiveness. ${ }^{12}$ For a variety of reasons, ${ }^{13}$ international legal scholars turned their attention to the implications of IR theory for international law only after the end of the Cold War, ${ }^{14}$ to the point that today rational choice and economic analyses of international law are very much in vogue. ${ }^{15}$ Contemporary international lawyers who have not yet mastered the differences between the Prisoners' Dilemma and Chicken ${ }^{16}$ or who lack a basic grasp of economic terminology (utility functions, externalities, Pareto efficiency, transaction costs, Coasean bargaining) jargon that was once, at most, the domain only of those who dealt with international economic law, ${ }^{17}$ increasingly risk missing out on a substantial body of cutting edge international law scholarship. ${ }^{18}$

\footnotetext{
${ }^{12}$ For a non-critical but comprehensive survey of traditional doctrines of international law, see MARTIN DiXON, TEXTBOOK ON INTERNATIONAL LAW 1-20 (5th ed. 2005).

${ }^{13}$ See, e.g., Jeffrey L. Dunoff \& Joel P. Trachtman, Economic Analysis of International Law, 24 YALE J. INT'L L. 1, 6 (1999) (attributing international lawyers' avoidance of L\&E to its "seemingly inaccessible methodologies," "supposedly conservative political prejudices," and "presumed denigration of international law").

${ }^{14}$ See Kenneth W. Abbott, Modern International Relations Theory: A Prospectus for International Lawyers, 14 YALE J. INT'L L. 335, 336 (1989) (“[O]verall, the discipline [of international law] has fallen behind other fields of law in developing an analytical approach informed by social science."); Anne-Marie Slaughter Burley, International Law and International Relations Theory: $A$ Dual Agenda, 87 AM. J. INT'L L. 205, 205 (1993) (comparing the view of international law as a futile discipline in the 1960s to its recent effectiveness); Anne-Marie Slaughter et al., International Law and International Relations Theory: A New Generation of Interdisciplinary Scholarship, 92 AM. J. INT'L L. 367, 367-68 (1998) (acknowledging the recent proliferation of international relations research). For current evaluations of the international relations/international law interface, see Jeffrey L. Dunoff \& Mark A. Pollack, International Law and International Relations: Introducing an Interdisciplinary Dialogue, in INTERDISCIPLINARY PERSPECTIVES ON INTERNATIONAL LAW AND International Relations: The State of the ART 3, 3-27 (Jeffrey L. Dunoff \& Mark A. Pollack eds., 2013); and Emilie M. Hafner-Burton, David G. Victor \& Yonatan Lupu, Political Science Research on International Law: The State of the Field, 106 AM. J. INT'L L. 47, 51 (2012).

${ }^{15}$ See, e.g., supra note 7.

${ }^{16}$ These are two of many variants of collective-action problems analyzed through game theory. For a succinct explanation, see TODD SANDLER, GLOBAL COLLECTIVE ACTION 20-30 (2004). For a fascinating critique of the ubiquity of the Prisoners' Dilemma attributing the dominance of Prisoners' Dilemma in political science research to path dependency, see Carol Rose, Game Stories, 22 YALE J.L. \& HUMAN. 369, 383 (2010).

${ }^{17}$ It is hardly coincidental that many of the most path-breaking, prominent, and proficient L\&E scholars of international law, such as Ken Abbott, Andrew Guzman, Alan Sykes, Joel Trachtman, and Michael Trebilcock, are also among the leading lights in international economic law.

${ }^{18}$ But see the fundamental critique of the influence of IR on international legal scholarship in the United States in MARTti KoskenNiEMI, THE GeNTLE CIVILIZER OF NATIONS: THE RISE AND FALL OF INTERNATIONAL LAW 1870-1960 3 (2001), which critiques the "conviction that international reform could be derived from deep insights about society, history, human nature or developmental laws of an international and institutional modernity," and asserts that it has "failed to produce or even support viable policies." For a spirited response, see Mark A. Pollack, Is International Relations Corrosive of International Law? A Reply to Martti Koskenniemi, 27 TEMP.
} 
The advent of economic analysis of international law is, in essence, the fusion of two complementary trends. First, on the demand side, the acknowledgement of the relative dearth of non-doctrinaire research methodology and disciplinary rigor in international legal studies ${ }^{19}$ has led some legal scholars to turn not only to IR theory, but more directly to classical economic theory. ${ }^{20}$ Second, but of no lesser importance, on the supply side, economic analysis of law has (in the United States and elsewhere) significantly impacted virtually all fields of law and jurisprudence, both in theory and in practice. ${ }^{21}$ For the disciples of $\mathrm{L} \& \mathrm{E}$, the application of its idiom to international law is simply another feather in their collective caps. ${ }^{22}$

Rational choice analysis of international law thus satisfies both international law's quest for methodological decorum and the L\&E school's ambitious mission of increased legal and social influence. Nonetheless, this marriage-the rationalization of international law-has not been harmonious, leading at times to disconcerting results. For many international lawyers, economic analysis of international law, for all its merits, will be forever tainted (and as a result, too easily ignored) because of its association with the crude revisiting and rehearsal of the "realist" claim that international law is not a system of law at all. $^{23}$ This is

INT'L \& COMP. L.J. 339, 340 (2013), where the author concludes that "Koskenniemi's critique of IR represents at best an anachronism, describing the early Cold War IR of our grandfathers rather than the contemporary field, and at worst a distortion of IR scholars' attitudes, aims, and influence on the legal profession."

${ }^{19}$ See Jack L. Goldsmith \& Eric A. Posner, A Theory of Customary International Law 97 (Univ. of Chi., John M. Olin Law \& Econ., Working Paper No. 63, 1999), available at http://papers.ssrn.com/sol3/papers.cfm?abstract_id=145972 ("Modern [customary international law] scholarship occupies the position that domestic legal scholarship held a century ago. Heavy reliance on cases and treatises gives scholars a distorted picture of actual state practices ...."); see also Anne-Marie Slaughter \& Steven R. Ratner, Appraising the Methods of International Law: A Prospectus for Readers, 93 AM. J. INT'L L. 291, 299 (1999) (noting that IR theory and L\&E theory claim to add rigor to international studies).

${ }^{20}$ See Dunoff \& Trachtman, supra note 13, at 50 ("[A]lmost every international law research subject could be illuminated, to some degree, by [economic analysis] research methods.").

${ }^{21}$ See, e.g., Anthony T. Kronman, Dean, Yale Law Sch., Remarks at the Second Driker Forum for Excellence in the Law (Sept. 29, 1994) (presenting L\&E as "the single most influential jurisprudential school in this country”), in 42 WAYNE L. REV. 115, 160 (1995).

${ }^{22}$ For example, Richard Posner, arguably the dean of the L\&E school, devoted very little attention to international legal issues in RICHARD A. POSNER, ECONOMIC ANALYSIS OF LAW 136-41 (6th ed. 2003), implying that international legal issues should be analyzed as any other legal subject, by equating treaty law with domestic contract law with respect to the concept of efficient breach.

${ }^{23}$ See Jack L. Goldsmith \& Eric A. Posner, A Theory of Customary International Law, 66 U. CHI. L. REV. 1113, 1176-77 (1999) (suggesting a conservative rational choice formulation of customary international law). But see PETER MALANCZUK, AKEHURST'S MODERN 
unfortunate. The field has produced many contributions and responses, ${ }^{24}$ more rigorously based on economic theory and method. Many of these contributions both effectively uphold the normative value of international law and go a long way toward explaining its functions, or at least toward presenting hypotheses to this end. There should be no doubt that rational choice and L\&E analyses have presented-and can continue to presentmany of the most enriching and challenging contributions to the ways we reflect upon international law. Even if its introduction has produced antagonism, the rational choice approach has much to offer, both positively and normatively.

However, the gaps in the existing literature-such as the substantial and substantive differences between studies ostensibly based upon the same methodology-only highlight the susceptibility of economic analysis of law to the political manipulation of assumptions and definitions. This risks robbing it of its main self-professed strength: its scientific basis and methodological parsimony. Moreover, even the most developed economic analyses of international law are ultimately little more than shadows of similar analyses generated by the neoliberal-institutionalist school of international relations, ${ }^{25}$ an important earlier generation of knowledge, still taught but now rarely practiced on its own. ${ }^{26}$ At times, such analyses have a tendency to frame what should rightly be hypotheses about state behavior

INTRODUCTION TO INTERNATIONAL LAW 6 (7th ed. 1997) (referring to the booming professional and academic work supporting international law and declaring " $[t]$ he old discussion on whether international law is true 'law' is therefore a moot point"). See generally Anne van Aaken, To Do Away with International Law? Some Limits to 'The Limits of International Law,' 17 EUR. J. INT'L L. 289 (2006) (discussing L\&E theory as developed by Posner and Goldsmith).

${ }^{24}$ See generally GUZMAN, supra note 7 (describing rational choice and the general theory of international law as they pertain to customary international law); TRACHTMAN, supra note 7 (describing customary international law).

${ }^{25}$ See GuZMAN, supra note 7, at 33-34 (reducing the workings of international law to the "three Rs" of reciprocity, retaliation, and reputation, which are remarkably reminiscent of the repertoire of IR theory of earlier periods). See generally Kal Raustiala, Refining the Limits of International Law, 34 GA. J. INT'L \& COMP. L. 423 (2006) (discussing the effects of economic theory as it applies to international law); see also TRACHTMAN, supra note 7, at 131-33 (describing the use of game theory in generating international treaties).

${ }^{26}$ Where in the recent past international relations studies could at least seem to be neatly divided into paradigmatic "-isms" - realism, neoliberalism, and constructivism-it is increasingly acknowledged that these schools share some common ground and, more importantly, that each approach has its explanatory strengths and weaknesses, jointly constituting the international relations "toolbox," suggesting a dialectic rather than linear or paradigmatic pattern of progress. See Mark Blyth, Structures Do Not Come with an Instruction Sheet: Interests, Ideas, and Progress in Political Science, 1 PERSP. ON POL. 695, 701-02 (2003) (arguing that "stark opposition and all-ornothing alternatives need not be the choice facing the discipline [of political science]"); see also Dunoff \& Pollack, supra note 14, at 37 (discussing the ongoing debate between realists and constructivists). 
as question-begging assumptions instead. Interestingly, IR researchers are cutting loose from the analytical strictures of perfect rational choice, ${ }^{27}$ while at the very same time international legal scholars are beginning to discover it. Legal research would do well to avoid rearguing intellectual debates now all but settled in the IR discipline. Additionally, although it has generated interesting hypotheses, L\&E's venture into international law has not been backed up by a requisite level of empirical substantiation. Hypotheses are advanced but rarely tested beyond the provision of anecdotal evidence typical of informal L\&E. In this respect, economic analysis of international law can-and should-be salvaged by developing a more rigorous empirical dimension. The generation of hypotheses is an important step in research, but as Milton Friedman wrote, "the only relevant test of the validity of a hypothesis is comparison of its predictions with experience." ${ }^{28}$

The most imperative of L\&E's assumptions is the assumption of rationality of states and other actors under international law, which leads us back to the question asked in opening: are states and other international actors "rational?" We can make this question more precise and indeed more interesting; instead of querying whether states are rational or not-there seems to be no self-evident or other reason to presume that states are inherently irrational ${ }^{29}$-the question ought to be: what is the nature of their rationality? Studies employing rational choice in the analysis of international legal problems and systems typically adhere to conventional assumptions about human rationality and apply them en banc to states. ${ }^{30}$

Only rarely are these assumptions somehow qualified, for example through the employment of "thin" rationality. ${ }^{31}$ Thin rationality is a framework in which states would be deemed rational in their behavior,

${ }^{27}$ See, e.g., Jonathan Mercer, Rationality and Psychology in International Politics, 59 INT'L ORG. $77,79-80(2005)$ (arguing that psychology complements rational choice because actors can exhibit irrational behaviors); Matthew Rabin, A Perspective on Psychology and Economics, 46 EUR. ECON. REV. 657, 660-62 (2002) (arguing that rational choice is unrealistic and should be complemented by psychology).

${ }^{28}$ MilTON Friedman, EsSAYS In POSITIVE EcONOMics 8-9 (1966).

${ }^{29}$ See Anne van Aaken, Towards Behavioral International Law and Economics: A Comment on Enriching Rational Choice Institutionalism for the Study of International Law, 2008 U. ILL. L. REV. 47, 58 (asserting that "[f]ew international lawyers would deny that states... act in predominantly rational ways").

${ }^{30}$ See, e.g., Andrew T. Guzman, The Design of International Agreements, 16 EUR. J. INT'L L. 579, $586(2005)$ (assuming that "states are rational beings; that they act in their own self-interest, at least as that interest is defined by the political leaders of the state; and that states are aware of the impact of their actions on the behavior of other states").

${ }^{31}$ On "thin" rationality, see generally DONALD P. GREEN \& IAN SHAPIRO, PATHOLOGIES of RATiOnal CHOICE THEORY: A CRITIQUe OF APPLICATIONS IN POLITICAL SCIENCE 17-19 (1994). 
pursuing self-interest within a certain set of preferences, but it is acknowledged that they set these preferences not by "objective" standards of utility or efficiency, but rather idiosyncratically, in accordance with their own emotional, cultural and historical charges "that many outsiders might find difficult to understand." 32 Such a contextualization of state behavior would appear obvious to traditional, regionalist, or otherwise specialist scholars and analysts of international politics but it is an important modifier to conservative economic analysis. Moreover, in the broader context of international legal research, it stumbles upon the can of worms of cultural relativism and erodes the paradigm of perfect rationality, making it highly contingent on specific assumptions about individual state or societal preferences and utility functions.

There is nothing inherently wrong with this; in IR, many explanations "are no longer parsimonious." ${ }^{33}$ Nevertheless, some rational choice analyses of international law might also generally concede the possibility of miscalculation by rational actors, though this is also not inconsistent with traditional expected utility theory, as only decisions that are haphazard, arbitrary, random, or otherwise a priori inutile are removed from the model. The latter cases are symptoms of irrationality, not of qualified rationality-divergences from perfect rationality are mistakes, not behavioral patterns.

What, then, is wrong with the perfect rationality model of international law and politics? Most clearly, it is empirically false; more accurately, it is empirically unsubstantiated. So far, international L\&E's chief weakness lies in its seeming reluctance to seriously test its hypotheses. In some cases, these hypotheses might be factually valid, and hence, useful; however, they usually remain hypotheses. As anywhere, with respect to international law, L\&E clearly needs to become more empirical and less theoretical, in which case it could be brought into the fold of the so-called new legal realism (not unlike the behavioral form of analysis discussed in this Article). ${ }^{34}$ However,

\footnotetext{
${ }^{32}$ Russel Korobkin \& Jonathan Zasloff, Roadblocks to the Road Map: A Negotiation Theory Perspective on the Israeli-Palestinian Conflict After Yasser Arafat, 30 YALE J. INT'L L. 1, 10 (2005).

${ }^{33}$ Deborah Kay Elms, New Directions for IPE: Drawing from Behavioral Economics, 10 INT'L STUD. REV. 239, 242 (2008). Parsimony is further discussed in Section III.C, infra.

${ }^{34}$ See Daniel A. Farber, Toward a New Legal Realism, 68 U. CHI. L. REV. 279, 296 (2001) (book review) (arguing that behavioral law and economic theory is as limited as pure rationality theory); Victoria Nourse \& Gregory Shaffer, Varieties of New Legal Realism: Can a New World Order Prompt a New Legal Theory?, 95 CORNELL L. REV. 61, 71-90 (2009) (discussing the various forms of new legal realism); Gregory Shaffer, A New Legal Realism: Method in International Economic Law Scholarship (emphasizing the importance of field work in legal realism), in INTERNATIONAL ECONOMIC LAW: THE STATE AND FUtURE OF THE Discipline 29, 39 (Colin B. Picker, Isabella D. Bunn \& Douglas W. Arner eds., 2008).
} 
a standard defense against this claim is that rationality is not intended to depict reality. It is a model-no more, no less. ${ }^{35}$ Nevertheless, international L\&E scholars rarely test their theories, yet often make significant claims about reality. Furthermore, some economic analysis, even if it is formally hypothetical and descriptive, includes a disguised or otherwise embedded normative element. Implicit in the assumptions of individual (or state) rationality is the view that individuals or states are and should be (perfectly) rational, and this is no longer a model, but a positive or normative claim.

Beyond international L\&E, however, studies of rationality have evolved into the gradual establishment of a behavioral school of economics that challenges basic assumptions of human rational choice, judgment, and decisionmaking with alternative, empirically based observations on cognitive psychology. Recently, these have been greatly popularized ${ }^{36}$ and, for better or for worse, cannot be ignored in current public policy debates. Would it not be possible and potentially productive to turn to these insights "to bring new and more accurate understandings of behavior and choice to bear" ${ }^{\text {37 }}$ on international law, subject to standard methodological qualifications and controls? Cognitive psychology has led to analyses of domestic legal systems and arrangements; it has also led to non-legal behavioral studies in IR, indeed with a long, if not dominant, scholarly tradition (especially in security studies). ${ }^{38}$ These efforts are certainly not without their failures and flaws, but conceptually, they hold great potential, and it would be analytically and discursively productive to now explicitly merge them into the idea of behavioral international law, as explained in the following Part. ${ }^{39}$

\footnotetext{
${ }^{35}$ See STEVEn SHAVELl, Foundations OF ECONOMic ANALYSIS OF LAW 1 (2004) ("The advantage of studying models is that they allow descriptive and normative questions to be answered in an unambiguous way...."). The emphasis is, therefore, on parsimony, rather than empirical accuracy.

${ }^{36}$ See generally, e.g., DAN ARIELY, PREDiCTABLy IRRATIONAL: THE HidDEN ForCES THAT SHAPE OUR DECISIONS (2009); DANIEL KAHNEMAN, THINKING, FAST AND SLOW (2011).

${ }^{37}$ Cass R. Sunstein, Introduction to BeHAVIORAL LAW AND ECONOMICS 1, 1 (Cass R. Sunstein ed., 2000).

${ }^{38}$ See, e.g., Robert Jervis, PERCEPTION AND MisPerception IN INTERnAtionaL POLITICS 117-201 (1976) (discussing the effects of rational and irrational actions in psychological theories as they pertain to international decisionmaking); YAACOV Y. I. VERTZBERGER, RISK TAKING AND DECISIONMAKING: FOREIGN MILITARY INTERVENTION DECISIONS 43-112 (1998) (using socioeconomic factors to discuss how people evaluate risks). See generally Jack S. Levy, Prospect Theory and International Relations: Theoretical Applications and Analytical Problems, 13 POL. PSYCHOL. 283 (1992) (discussing the evaluation of international relations under prospect theory).

${ }^{39}$ Indeed, the idea of behavioral international law research flows naturally from the problematique of nonempirical, rational choice approaches to international law. See generally van Aaken, supra note 29 (offering several new methods of utilizing social science in international legal analysis).
} 
Before moving into a more detailed explanation of the implications of behavioral economics for international law, it is important to at least briefly note other well-developed critiques and sophisticated alternatives to the standard rational choice approach. Given the limitations of rational choice methods in international law, some have pursued paths of social constructivism and sociology of law by explaining state behavior in sociological terms. ${ }^{40}$ Moreover, one can seek out the ways in which the rationality of individuals, as well as collectives, is socially constructed by economic theory through an examination of studies in the field of economic sociology. ${ }^{41}$ The interaction between such sociological approaches and the use of insights from behavioral economics and cognitive psychology is complex and multileveled. For example, in their important work on acculturation and socialization in international law, Ryan Goodman and Derek Jinks refer not only to social pressures to conform, but also to cognitive pressures. ${ }^{42}$ They deal with cognitive features as part of the environment in which organizations, such as states, act. ${ }^{43}$ And of course,

\footnotetext{
${ }^{40}$ See, e.g., Sungjoon Cho, Beyond Rationality: A Sociological Construction of the World Trade Organization, 52 VA. J. INT'L L. 321, 334-53 (2012) (proposing a sociological framework to understand and improve operations of the World Trade Organization since rationalism overlooks vital social dimensions of the organization and leaves theoretical gaps); Moshe Hirsch, The Sociology of International Economic Law: Sociological Analysis of the Regulation of Regional Agreements in the World Trading System, 19 EUR. J. INT'L L. 277, 288 (2008) (describing how the social constructivist approach posits that states' interests and identities are constructed by social structures and acknowledges that states are embedded in a set of social relations where their identity is defined by their interaction with other international actors); see also Moshe Hirsch, The Sociology of International Law: Invitation to Study International Rules in Their Social Context, 55 U. TORONTO L.J. 891, 892 (2005) (discussing how recently international law scholars have used sociology to study international legal concepts, which has redefined international law and our understanding of its social limits).

${ }^{41}$ See Michel Callon, An Essay on Framing and Overflowing: Economic Externalities Revisited by Sociology (describing the impact that sociological accounts of externalities may have in negotiations, helping us understand the dynamics of markets and their reforms), in THE LAWS OF THE MARKETS 244, 264-66 (Michel Callon ed., 1998); Neil Fligstein, The Political and Economic Sociology of International Economic Agreements (discussing how economic sociology offers insights into understanding the structure of global markets), in THE HANDBOOK OF ECONOMIC SocIOLOGY 183, 201 (Neil J. Smelser \& Richard Swedberg eds., 2d ed. 2005). I am grateful to Andrew Lang for pointing out this direction of inquiry, which has potentially interesting interactions with behavioral economics.

${ }^{42}$ See Ryan Goodman \& Derek Jinks, How to Influence States: Socialization and International Human Rights Law, 54 DUKE L.J. 621, 684 (2004) (“[C]ognitive pressures suggest that states may be more inclined to conform their behavior to community expectations-and that they are unlikely to sustain, over the long term, an idiosyncratic interpretation of any norm that the international community considers central."); infra Section IV.B (returning to cognitive pressures to conform in the context of international judging).

${ }^{43}$ See Ryan Goodman \& Derek Jinks, Toward an Institutional Theory of Sovereignty, 55 STAN. L. REV. 1749, 1755-56 (2003) (studying how the cognitive environment guides state actors by
} 
behavioral research and sociological scholarship share a heightened appreciation and requirement for empirical grounding. In short, there is still much to explore about the intellectual and methodological pathways that run between sociological approaches and psychological research methods in international law. ${ }^{44} \mathrm{My}$ focus here is on the development of the latter.

\section{WHY BEHAVIORAL INTERNATIONAL LAW?}

Despite the apparent primacy of classical or traditional rational choice theory in international legal scholarship, contemporary formulations of rationality are far from monolithic. Traditional L\&E employs classical theoretical economic assumptions of perfect human rationality. It assumes that under conditions of resource scarcity, human beings act as utilitymaximizing, self-interested beings that respond to incentives in accordance with stable preference priorities. ${ }^{45}$ These assumptions enable L\&E scholars to discuss and analyze the ramifications of such rational behavior for the design and effectiveness of law and legal institutions, both market- and nonmarket-oriented. But where traditional $L \& E$ adheres to objective conceptions of ideal rationality personified in a hypothetical "homo economicus," ${ }^{46}$ and international L\&E imagines a "civitas economica," behavioral $\mathrm{L} \& \mathrm{E}$ seeks to incorporate insights from empirical research in the field of cognitive psychology regarding human rationality as it is observed in reality and practice. Experimental research has shown that in many cases human behavior diverges from theoretical assumptions about rationality; consequently, "[ $\mathrm{t}] \mathrm{he}$ task of behavioral law and economics, simply stated, is to explore the implications of actual (not hypothesized)

structuring the field of possible action and the ways states inherit and satisfy specific expectations).

${ }^{44}$ Indeed, it is not surprising that some of the very first research on international law employing behavioral insights was brought forward by sociological scholars. See Paul Slovic, David Zionts, Andrew K. Woods, Ryan Goodman \& Derek Jinks, Psychic Numbing and Mass Atrocity (discussing possible ways to overcome "psychic numbing," or turning off emotions in the face of mass atrocities, to mobilize global public sentiment and changes in international law), in The Behavioral Foundations OF PUbliC POLICY 126, 136 (Eldar Shafir ed., 2013).

${ }^{45}$ See Guzman, supra note 30, at 586 (assuming that states are rational beings acting in their own self-interest); see also GARY S. BECKER, THE ECONOMIC APPROACH TO HUMAN BEHAVIOR 14 (1976) (“[A]ll human behavior can be viewed as involving participants who maximize their utility from a stable set of preferences and accumulate an optimal amount of information and other inputs in a variety of markets.").

${ }^{46}$ For the development of the term, see Joseph Persky, Retrospectives: The Ethology of Homo Economicus, 9 J. ECON. PERSP. 221, 230 (1995), which explains that the "economic man" is useful not to indicate that humans are rational, but that social science works best when its findings are limited by imposing some basic assumptions. 
human behavior for the law." ${ }^{47}$ After a few decades of significant experimental research by cognitive psychologists on human decisionmaking, it is well-acknowledged that, in many ways, human individuals are decidedly not rational in the ideal sense. Human action is not only "shaped by relevant economic constraints but is highly affected by people's endogenous preferences, knowledge, skills, endowments, and a variety of psychological and physical constraints." ${ }^{, 4}$

A behavioral-economic approach to law supplants the basic assumptions of rationality with several qualified statements on human decisionmaking, based on experimental observations of human behavior. ${ }^{49}$ Like classic economic rationality, behavioral economics is first and foremost a theory of judgment. The former emphasizes models based upon objective methods of utility maximization. The latter, similarly, embraces the importance of autonomous decisionmaking, but strives to understand how it plays out in reality. Behavioral economics varies by taking into account the real boundaries and attributes of human character and capacities.

Indeed, for the reasons noted above, perfect rationality is a theory of judgment that also includes elements of a normative theory. In contrast, behavioral theory has a very strong empirical, descriptive element. This is not to say that it cannot provide the basis for normative analysis. Of course it can; understanding how actors-states or individuals-behave in practice is a crucial element in designing rules with the instrumental intention of influencing this behavior. ${ }^{50}$ Indeed, advocates of the behavioral approach to

\footnotetext{
${ }^{47}$ Christine Jolls, Cass R. Sunstein \& Richard H. Thaler, A Behavioral Approach to Law and Economics, in BEHAVIORAL LAW AND ECONOMICS, supra note 37, at 13, 14.

${ }^{48}$ Francesco Parisi \& Vernon Smith, Introduction to THE LAW AND ECONOMICS OF IRRATIONAL BEHAVIOR 1, 1-2 (Francesco Parisi \& Vernon L. Smith eds., 2005).

${ }^{49}$ This does not mean, however, that the rational choice framework of analysis is entirely rejected. As Thomas S. Ulen and Russell B. Korobkin stated:

[W]e do not argue that the edifice of rational choice theory, which underlies so much of legal scholarship, be ripped down. Rather, we suggest that it be revised, paying heed to important flaws in its structure that unduly and unnecessarily limit the development of a more nuanced understanding of how law affects society.

Korobkin \& Ulen, supra note 8, at 1144.

In other words, other central tenets of economic analysis of law-especially the idea that actors respond to incentives that the law creates or influences-are retained. For a purist response, implying that the rational choice framework and the assumption of rationality are a package deal, see Richard A. Posner, Rational Choice, Behavioral Economics, and the Law, 50 STAN. L. REV. 1551, 1567 (1998). Posner explains that even when faced with anomalous behavior, the rational choice economist will look for a theoretical modification that might accommodate an apparent anomaly to the assumption of rationality. Id.

${ }^{50}$ See Russell Korobkin, The Problems with Heuristics for Law ("A large body of evidence, now familiar to the legal community, demonstrates that individual judgment and choice is often driven
} 
law consider it to be both normatively neutral, because it is not necessarily wedded to welfare economic analysis, and normatively relevant, because of its ability to point to systematic decision errors that reduce the capacity of the law to promote social welfare. ${ }^{51}$

Simplified, the central concept underlying the study of behavioral theory is the idea of bounded rationality, which recognizes that human cognitive capabilities are not perfect or infinite. ${ }^{52}$ The human brain makes shortcuts in judgment and decisionmaking that diverge from expected utility theory. Limiting aspects of bounded rationality and the shortcuts taken to overcome them-generally known as biases and heuristics, respectively-inevitably cause human decisions that appear erroneous when compared with perfectly rational outcomes. Having said this, it is important to understand that behavioral economics does not aspire to replace one ideal-type decisionmaker (a perfectly rational one) with another (rationally imperfect) decisionmaker. Rather, the behavioral research agenda aims to explore the characteristics of the real decisionmaking processes of different types of actors under different circumstances. So far, various important generalizable characteristics have been identified, but behavioralists do not claim that they exist equally among all decisionmakers in all cases and under all conditions.

Momentarily setting this caveat of contingency aside, perhaps the single most important insight of behavioral psychology discovered through economic analysis derives from prospect theory. ${ }^{53}$ Prospect theory questions

by heuristic-based reasoning as opposed to the pure optimization approach presumed by rational choice theory."), in HEURISTICS AND THE LAW 45, 45 (G. Gigerenzer \& C. Engel eds., 2006).

${ }^{51}$ See Avishalom Tor, The Methodology of the Behavioral Analysis of Law, 4 HAIFA L. REV. 237, 314-25 (2008) (describing how "the behavioral analysis of law is simultaneously normatively neutral and normatively relevant[,] ... normatively neutral because it is not committed to any specific legal goal or value" and normatively relevant because it provides a tool to look at the impact of systematic decision errors on social welfare).

${ }^{52}$ Though not in name, the concept of bounded rationality was first introduced into academic discourse by Herbert Simon in A Behavioral Model of Rational Choice. See Herbert A. Simon, $A$ Behavioral Model of Rational Choice, 69 Q.J. ECON. 99, 114 (1955) (suggesting the replacement of "economic man" with "a choosing organism of limited knowledge and ability" whose "simplifications of the real world for purposes of choice introduce discrepancies between the simplified model and the reality"). For a collection of studies on the topic, see generally Bounded Rationality: The AdaPtive Toolbox (G. Gigerenzer \& R. Selten eds., 2001). While the notion of boundedness implies a limitation of rationality, some of the literature views it as enabling effective decisionmaking. See MARK Kelman, THE Heuristics Debate 87 (2011) (noting that economists who speak of "bounded rationality" may "fail to account adequately for the fact that the best way of solving many problems ... is to use a scaled-back computational method").

${ }^{53}$ See Daniel Kahneman \& Amos Tversky, Prospect Theory: An Analysis of Decision Under Risk, 47 ECONOMETRICA 263, 274 (1979) (presenting an alternative account of individual decisionmaking under risk for simple prospects with monetary outcomes and stated probabilities 
the validity of the Coase theorem, which both expresses and relies upon the idea of perfect rationality. In Coasean economics, in the absence of transaction costs, the initial assignment of resources or entitlements is not determinative of their ultimate allocation. Cost-benefit bargaining between rational actors will assign the entitlements efficiently to the actor who values them the most, regardless of the starting point. ${ }^{54}$ The Coase theorem is elemental for classical economic analysis of the law because it neutralizes the psychological aspects of human interactions. Indeed, it is the basis of L\&E's overarching parsimony. However, experimental observations have shown repeatedly, in varying circumstances, that initial assignments of entitlements do matter. Initial assignments significantly influence actors' decisions, in particular, their willingness to part with their entitlements. In Coasean terms, $\$ 10$ (or any other item of value-in international affairs this could be territory, resources, or any other asset of political or symbolic importance) has equal worth, whether gained or lost, whether compared to rags or to riches. Yet in real life, people do not regard losses and gains of equal size indifferently. For example, they will often invest more in the prevention of loss than in the generation of gains of the same amount. This is the logic that underlies a variety of related terms that derive or are otherwise related to the ideas of prospect theory, such as loss aversion, ${ }^{55}$ the endowment effect, ${ }^{56}$ and framing effects. ${ }^{57}$

that "distinguishes two phases in the choice process: an early phase of editing and a subsequent phase of evaluation").

${ }^{54}$ R. H. Coase, The Problem of Social Cost, 3 J.L. \& ECON. 1, 2-8 (1960) (illustrating how a farmer and a cattle raiser bargain differently over damage liability for a straying cattle that destroys crops based on the cost of crops and cattle and what is most efficient for each actor).

${ }^{55}$ For the most comprehensive and thought-provoking study of loss aversion in legal contexts, see Eyal Zamir, Loss Aversion and the Law, 65 VAND. L. REV. 829, 830 (2012), where the author theorizes that "[g]ains and losses are defined relative to a baseline or reference point. The value function is normally steeper for losses than gains, indicating loss aversion." See also EYAL ZAMIR, LAW, PSYCHOlOGY, AND MORAlitY: THE ROlE OF LOSS AVERSION 1-2 (2015) (explaining that "people's preferences and choices are a function not only of the expected value of different outcomes, but also of their risk aversion, which in turn depends on their overall assets" and that gains and losses are defined in relation to a reference point making the value function for losses convex, or people more likely to accept a smaller gain just to avoid a potential larger loss).

${ }^{56}$ Daniel Kahneman, Jack L. Knetsch \& Richard H. Thaler, Experimental Tests of the Endowment Effect and the Coase Theorem, 98 J. POL. ECON. 1325, 1325 (1990) (positing that the endowment effect, described as "measures of willingness to accept greatly exceed[ing] measures of willingness to pay," persists in market settings); $i d$. at 1326 (citing a hypothesis that many discrepancies between willingness to accept and willingness to pay "reflect a genuine effect of reference positions on preferences" and the endowment effect is this "increased value of a good to an individual when the good becomes part of the individual's endowment"); see also Russell Korobkin, Behavioral Economics, Contract Formation, and Contract Law (describing how the endowment effect is also related to the phenomenon known as "status quo bias"), in BEHAVIORAL LAW AND ECONOMICS, supra note 37, at 116. 
Prospect theory and the various phenomena it informs present a fundamental diversion from perfect rationality. If law-including international law-has the aim of directing the behavior of actorsincluding states and other actors engaged with international law-it must take prospect theory into account, at least in instances where it can empirically be shown to have a significant impact.

There are additional psychological kinks in rationality, systematically substantiated by scientific experiments in cognitive psychology. For example, under the availability bias, "[p]eople tend to think that risks are more serious when an incident is readily called to mind." ${ }^{58}$ Under the so-called hindsight bias, people tend to overestimate ex ante predictions they had made "concerning the likelihood of an event's occurring after learning that it actually did occur." ${ }^{59}$ Probability matching is a proven tendency of human subjects to make choices that match the relative frequency of events, instead of utility-maximizing choices that would presuppose the occurrence of the most probable (e.g., when faced with a six-sided die with four red sides and two white sides and asked to repeatedly guess the color that would be rolled, people choose red twothirds of the time, instead of the utility-maximizing solution that would choose red every time) ${ }^{60}$

Like prospect theory, availability bias, hindsight bias, probability matching, and other biases and heuristics hold important lessons for the design of law and legal process in a variety of areas. For example, it has

\footnotetext{
${ }^{57}$ Framing effects arise when alternative descriptions of the same decision problem give rise to different preferences. Thus, in one classic example, people who have lost $\$ 10$ on the way to the theater will tend to nonetheless purchase a ticket; but people who have lost a pre-purchased ticket to the theater worth $\$ 10$ will not, even though in expected utility terms, the rational decision should be the same. See, e.g., Amos Tversky \& Daniel Kahneman, The Framing of Decisions and the Psychology of Choice, 211 SCI. 453, 457 (1981) (providing the ticket example to illustrate how an existing account affects a decision); Amos Tversky \& Daniel Kahneman, Rational Choice and the Framing of Decisions, 59 J. BUS. S251, S255-62 (1986) (providing additional examples of framing effects that control the representation of options and explain invariance).

${ }^{58}$ Sunstein, supra note 37 , at 5 .

${ }^{59}$ Thomas S. Ulen, Human Fallibility and the Forms of the Law: The Case of Traffic Safety, in THE LAW AND ECONOMICS OF IRRATIONAL BEHAVIOR, supra note 48, at 397, 410; see also Baruch Fischhoff, Hindsight $\neq$ Foresight: The Effect of Outcome Knowledge on Judgment Under Uncertainty, $1 \mathrm{~J}$. EXPERIMENTAL PSYCHOL.: HuM. PERCEPTION \& PERFORMANCE 288, 298 (1975) ("Judges may estimate the likelihood of a reported outcome by initially assigning it $100 \%, \ldots$ then looking for reasons to adjust downward from there. Adjustment from initial values is typically inadequate and would produce creeping determinism ....").

${ }^{60}$ See Richard F. West \& Keith E. Stanovich, Is Probability Matching Smart? Associations Between Probabilistic Choices and Cognitive Ability, 31 MEMORY \& COGNITION 243, 244 (2003) (providing the die example and its heuristic results as demonstrative of probability matching responses when the frequencies of hypothetical outcomes are inferable from the outset).
} 
been argued that availability bias, compounded by social and political processes, makes risk regulators vulnerable to inefficient decisions; ${ }^{61}$ and hindsight bias operating in conjunction with other biases prevent increased driver tort liability from reducing traffic accidents. ${ }^{62}$ Others have argued that probability matching supports employing a risk-based rather than a harm-based liability scheme in tort law, inducing individuals to behave more like maximizers than probability matchers. ${ }^{63}$ Similar lessons surely exist for international law.

These expressions of bounded rationality show that in many situations, individuals are incapable of rational utility-maximization because of the way the human mind processes information and reacts to particular circumstances. In many cases, heuristics can be effective in reducing costs of decisionmaking. But at the same time, they may also lead to systematic and repeated errors. In addition to bounded rationality, cognitive psychology has shown that individuals may have only bounded willpower. ${ }^{64}$ This concept significantly undermines the premises of classical rational choice. People sometimes act against their own interests, even when fully informed and conscious of the damage they may be inflicting upon themselves. The classic example is habitual smokers who do not kick the habit, even if they declare that they would like to. While this may be attributable to substance addiction, behaviorists have shown that bounded willpower is influential in other areas that are relevant to law, such as lack of self-control in criminal behavior. ${ }^{65}$

Finally, to complete the picture, in contrast to rational choice's assumptions of self-interest, people sometimes deliberately act contrary to

\footnotetext{
${ }^{61}$ See Timur Kuran \& Cass R. Sunstein, Availability Cascades and Risk Regulation, 51 STAN. L. REV. 683, 746 (1999) ("[A]vailability cascades constitute a major, perhaps the leading, source of the risk-related scares that have cramped federal regulatory policy at both the legislative and executives levels.... [C] ascades force governments to adopt expensive measures without careful consideration of the facts.").

${ }^{62}$ See Ulen, supra note 59, at 414 (describing how "the presence of the hindsight bias suggests that tort law may not work as well as rational choice theory had hoped to create incentives to take care" because there may be nothing that manufacturers or drivers can do to avoid liability if an accident occurs and juries assume they are liable).

${ }^{63}$ See Ehud Guttel \& Alon Harel, Matching Probabilities: The Behavioral Law and Economics of Repeated Behavior, 72 U. CHI. L. REV. 1197, 1199 (2005) ("[P]robability matching shows the advantages of using a risk-based liability system (imposing costs on the creation of risks) rather than the use of a harm-based liability system (imposing costs only for the creation of risks that materialize in harm).").

${ }^{64}$ See Jolls, Sunstein \& Thaler, supra note 47 , at 15.

${ }^{65}$ See, e.g., James Q. Wilson \& Allan Abrahamse, Does Crime Pay?, 9 Just. Q. 359, 368-71 (1992) (analyzing criminal earnings per day in prison and suggesting that criminals' opportunism and focus on the present (i.e., discounting future costs of punishment) leads them to decisions that can render classical deterrence inefficient).
} 
their own interests in the name of fairness, to benefit others. Evidently, in many cases, the human utility function includes values relating to the utility of others. This aspect of human behavior is sometimes referred to as "bounded self-interest." ${ }^{\text {"T }}$ The calculus of fairness in actual rationality also includes the expectation of fair treatment from others. ${ }^{67}$ Both of these aspects of fairness consideration can be demonstrated through consistent experimental results in "ultimatum games," in which subjects regularly make offers and responses that diverge from the rational economic prediction. ${ }^{68}$ These results are preserved even when agents do not know each other and possible reputational effects or social contexts are controlled for, suggesting that fairness is not (only) a social phenomenon but one that is embedded in human rationality. ${ }^{69}$

Behavioral theory should not necessarily be seen as contradictory to rational choice; in many ways it supplements and completes it. ${ }^{70}$ But these experimental findings have suggested significant qualifications to rational choice-based social analyses and hold important implications for the L\&E description and prescription of law. ${ }^{71}$ This nutshell explanation of behavioral economics and its effects on rational analysis of law is neither novel nor exhaustive. It is furnished here mainly to inform the question whether behavioral analysis could make a difference to international legal scholarship. If we assume, for the sake of argument, that the rationality of states and other international actors, or at least of those individuals and groups who determine state behavior is also "bounded," that biases and heuristics impact their choices and decisions, then the answer to this question is undoubtedly positive. In essence, any area of international law that can be explained or analyzed in terms of rational choice-humanitarian law, trade law, environmental law, arms control, migration law, or more general aspects of international law such as treaty-making or adjudication-could

\footnotetext{
${ }^{66}$ See Jolls, Sunstein \& Thaler, supra note 47 , at 16.

${ }^{67}$ See Elms, supra note 33, at 255 (describing concerns of fairness to others in the behavior of individuals).

${ }^{68}$ For a detailed description, see Jolls, Sunstein \& Thaler, supra note 47, at 21-26.

${ }^{69}$ But see generally Barbara A. Mellers et al., Group Report: Effects of Emotions and Social Processes on Bounded Rationality, in BOUNDED RATIONALITY, supra note 52, at 263, and Joseph Henrich et al., Group Report: What Is the Role of Culture in Bounded Rationality?, in BOUNDED RATIONALITY, supra note 52 , at 343 , for a discussion of the role of society and culture in the development of behavioral biases and heuristics.

${ }^{70}$ Whether behavioral L\&E challenges or rather complements traditional L\&E is a question discussed in Christine Jolls, On Law Enforcement with Boundedly Rational Actors, in THE LAW AND ECONOMICS OF IRRATIONAL BEHAVIOR, supra note 48.

${ }^{71}$ Conservative L\&E remains unmoved by these findings because "the concept of rationality used by the economist is objective rather than subjective, so that it would not be a solecism to speak of a rational frog." See POSNER, supra note 22, at 17.
} 
benefit from the incorporation of behavioral economics, and some examples will be suggested later in this Article. Strikingly, however, despite the great potential that behavioral analysis holds for these areas of cardinal importance, one hardly finds recourse to behavioral science in international legal literature, L\&E, or otherwise. ${ }^{72}$ The scarcity of behavioral research on international legal issues is evident even in the increasing literature on international risk regulation, which is a prime area for behavioral study. ${ }^{73}$

Even leading scholars with a keen interest and high degree of proficiency in behavioral analysis of domestic law seem to refrain from applying behavioral insights when engaging in questions of international law. For example, in a lucid negotiation-theory analysis of the ongoing impasse in Israeli-Palestinian peace talks, Korobkin and Zasloff have employed a rational choice negotiation framework that allows for

\footnotetext{
${ }^{72}$ First swallows have appeared, however. For discussions of applications to international humanitarian law, see Tomer Broude, Presentations at the Minerva Center for Human Rights Conference on Proportionality in Armed Conflict, Jerusalem: Behavioral Framing Effects and Proportionality in IHL (Nov. 2010), available at http://prezi.com/ayfsnphh5i3h/framing-ihl. See also Ashley Deeks, Cognitive Biases and Proportionality Decisions: A First Look (unpublished manuscript), available at http://law.huji.ac.il/upload/6_AshleyDeeks_p.pdf. For an analysis of the psychological causes for lack of affect toward genocide and mass atrocities, with operative recommendations in the areas of human rights and international institutions, see Slovic et al., supra note 44 , at 136 . For an application of the availability bias to bilateral investment treatymaking, see generally Lauge N. Skovgaard Poulsen \& Emma Aisbett, When the Claim Hits: Bilateral Investment Treaties and Bounded Rational Learning, 65 WORLD POL. 273 (2013); Lauge N. Skovgaard Poulsen, Bounded Rationality and the Diffusion of Modern Investment Treaties, 58 INT'L STUD. Q. 1 (2014); and Lauge N. Skovgaard Poulsen, Letting Down the Guard: Developing Countries, Investment Treaties, and Bounded Rationality (unpublished manuscript) (on file with author). Two recent contributions take very different, but equally stimulating, behavioralempirical approaches to treaty formation. See generally Jean Galbraith, Treaty Options: Towards a Behavioral Understanding of Treaty Design, 53 VA. J. INT'L L. 309 (2013) (employing database research to analyze the role of treaty reservations); Emilie M. Hafner-Burton et al., Decision Maker Preferences for International Legal Cooperation, INT'L ORG. (forthcoming 2014) (using surveybased research to analyze the influence of behavioral traits of key treaty negotiators on treaty formation). More general contributions include Anne van Aaken, Behavioral International Law and Economics, 55 HARV. INT'L L. J. 421 (2014); Anne van Aaken \& Tomer Broude, Behavioral Economic Analysis of International Law, in RESEARCH HANDBOOK OF LAW AND ECONOMICS OF PUBLIC INTERNATIONAL LAW (Edward Elgar ed., forthcoming 2015); and ANNE VAN AAKEN \& TOMER BROUDE, BEHAVIORAL ECONOMICS AND INTERNATIONAL LAW (forthcoming 2016).

${ }^{73}$ But for notable exceptions, see David A. Dana, A Behavioral Economic Defense of the Precautionary Principle, 97 NW. U. L. REV. 1315 (2003); Tracey Epps, Reconciling Public Opinion and WTO Rules under the SPS Agreement, 7 WORLD TRADE REV. 359 (2008); Cass R. Sunstein, Beyond the Precautionary Principle, 151 U. PA. L. REV. 1003 (2003); Markus Wagner, Law Talk V. Science Talk: The Languages of Law and Science in WTO Proceedings, 35 FORDHAM INT'L L.J. 151 (2011); and Lesley Wexler, Limiting the Precautionary Principle: Weapons Regulation in the Face of Scientific Uncertainty, 39 U.C. DAVIS L. REV. 459 (2006).
} 
miscalculation firmly within the "expected utility" tradition. ${ }^{74}$ They do not, however, discuss the potential insights of behavioral theory in the IsraeliPalestinian context-even though Korobkin has separately addressed the role that heuristics and biases play in bargaining more generally, and how the acknowledgement of their existence can help negotiators either adjust their own decisions in order to reach normative results or take advantage of their counterparts in maximizing the terms negotiated. ${ }^{75}$ These behavioral insights, if applied to the Israeli-Palestinian context, are non-trivial. Consider, for example, the possible role of overconfidence and hindsight bias in both Israeli and Palestinian positions in general; or of the fairness bias in the meltdown of the Camp David talks in 2000, in particular, which could be analyzed as an ultimatum game; or the influence of endowment effects evident in Israel's entrenched occupation and settlement policy on its negotiating positions; or the impact of the availability bias as triggered by recurring terrorist attacks on Israeli risk assessments that have informed its security policies in the occupied territories as well as its negotiating positions. These frameworks of analysis are not pursued in this Articlethey are only mentioned here to demonstrate the hesitation of behavioral legal analysts to apply their knowledge about human decisionmaking to international legal affairs.

Why is there such reticence, to say the least, to apply behavioral theory to international law? The reasons themselves may be behavioral, but that is beside the point. The question is whether there are any methodological justifications for refraining from doing so. I now turn to discuss a number of particular obstacles or objections to the application of behavioral economics to international law, which have perhaps so far chilled the advent of this project.

\footnotetext{
${ }^{74}$ See Korobkin \& Zasloff, supra note 32, at 9 (assuming that Israel and Palestine engage in rational behavior when making decisions or taking actions).

${ }^{75}$ See generally Russell B. Korobkin \& Chris Guthrie, Heuristics and Biases at the Bargaining Table, 87 MARQ. L. REV. 795 (2004). Another scholar who has applied behavioral economics to domestic legal issues, but standard traditional choice to international law, is Francesco Parisi. Compare Parisi \& Smith, supra note 48, at 9 (recognizing the "mainstreaming of behavioral theory and the ongoing process of incorporation of psychological findings in the process of economic modeling), with Francesco Parisi \& Catherine Ševčenko, Treaty Reservations and the Economics of Article 21(1) of the Vienna Convention, 21 BERKELEY J. INT'L L. 1, 4-13 (2003) (applying game theory principles to understand states' reservations to treaties). Treaty reservations are indeed a prime area for behavioral research, as demonstrated by Galbraith, supra note 72.
} 


\section{OBJECTIONS TO BEHAVIORAL INTERNATIONAL LAW AND METHODOLOGICAL RESPONSES}

One can raise several theoretical and methodological objections to a behavioral approach to international law. First, cognitive psychology and behavioral economics relate primarily to the conduct of individuals as (obviously) unitary actors, while the main subjects of international law are collective entities, primarily states. Second, the main strength of the claims made by cognitive psychology regarding rationality and decisionmaking is its grounding in empirical observations derived from experiments made with human subjects, which are difficult and perhaps impossible to replicate meaningfully in the context of international law and international relations. Third, the parsimony of traditional rational choice analyses of international interactions is superior to that of bounded rationality, although the latter adds layered and contingent dynamics to otherwise more straightforward hypothetical mechanics. These are all legitimate objections. Notably, they could be voiced from practically all corners-by realists, traditional rationalists, behavioralists, and non-rationalists, albeit all for different reasons. However, there are good responses to each objection, as explained below, and the objections themselves are not sufficient to reject the project. Rather, they must be considered in the design of research methodologies that incorporate behavioral insights into the analysis of international law. I will deal with them in the order of their importance.

\section{A. The Individual Focus of Behavioral Theory}

Under this objection, a behavioral approach to international law would be faulted if it examined the conduct of states because it would ostensibly be making a leap of faith from the methodological individualism ${ }^{76}$ on which behavioral theory and research are premised, to methodological statism. ${ }^{77}$ Put differently, states as constructed legal personalities do not necessarily

\footnotetext{
${ }^{76}$ The term is used here loosely to refer to cognitive psychology's focus on the individual, without any statement about the theoretical framing of the relationship between the individual and society in the social sciences. For a comprehensive survey and discussion of this grand debate, see generally LARS UDEHN, METHODOLOGICAL INDIVIDUALISM: BACKGROUND, HISTORY AND MEANING (2001)

${ }^{77}$ See, for example, the objection to the application of prospect theory to decisionmaking of states, in Eldar Shafir, Prospect Theory and Political Analysis: A Psychological Perspective, 13 POL. PSYCHOL. 311, 313-14 (1992). Notwithstanding the objection, for such theoretical applications in specific international contexts, see, for example, Jack S. Levy, Loss Aversion, Framing, and Bargaining: The Implications of Prospect Theory for International Conflict, 17 INT'L POL. SCI. REV. 179, 180 (1996), and Rose McDermott, Prospect Theory in International Relations: The Iranian Hostage Rescue Mission, 13 POL. PSYCHOL. 237, 245-52 (1992), both of which apply prospect theory to state leaders and small decisionmaking groups, rather than to states as unitary actors.
} 
share the imperfections of individuals or, by some accounts, necessarily do not. There are at least three responses to this criticism, each with its own methodological consequences, corresponding to three levels of analysis: (1) the state as a unitary actor; (2) decisionmaking collectives in international law; and (3) the individual as a decisionmaker in international law.

\section{The State as a Unitary Actor?}

This is perhaps the most difficult of the objections, but ultimately, it does not hold. First, quite bluntly, to the extent that this objection was voiced from the traditional quarters of realists, $L \& E$ analysts, and international lawyers, the initial response should be to note the hypocrisy of the criticism. All of these traditional groups have tended to do exactly the same, equating states to individual agents and considering the state as a usually unitary actor and decisionmaker. Is there any reason, however, to suppose-or any substantiation to that effect-that states, even when seen as black boxes or billiard balls (i.e., without looking into their internal decisionmaking processes) are any more perfectly rational than individuals? If the general rules of human behavior are better captured by the concept of bounded rationality, the validity of an assumption that states conduct themselves within the dictates of perfect rationality would be an exception to that rule. Indeed, there are good reasons to think that states are less rational because decisions are made by both agents and collectives. The empirical burden of proving the validity of a decisionmaking theory may therefore rest not upon a loose behavioral approach, but rather upon traditional rationalist analyses whose assumptions are stricter. These would then have to explain how states overcome the bounded rationality of the individuals that compose them and perfect their own rationality. Generally, there are two ways to do this: by looking beyond the state and by looking within the state.

Looking beyond the state, the argument against applying behavioral economic analysis to states would be that even if states naturally acted according to bounded rather than ideal rationality, the international political and legal environment in which states act would somehow have a corrective effect, leading them to become more perfectly rational. Put differently, the costs associated with behaving in imperfectly rational ways would lead states to adjust their behavior accordingly. Notably, a similar debate has arisen with respect to the rationality of another type of nonindividual, collective legal actor: the firm. Traditional economic analysts of law have claimed that selection effects in market contexts will discipline bounded rational behavior in firms, rendering empirical insights about 
individual behavior immaterial. ${ }^{78}$ Indeed, some proponents of behavioral analysis have conceded this as a valid point. ${ }^{79} \mathrm{With}$ respect to states, this is certainly an important issue, but it should be viewed as an impetus to perform behavioral research of international law, requiring empirical inquiries into the degree to which state behavior in discrete situations conforms to expected rational benchmarks, rather than as an obstacle.

Indeed, in many-arguably, most-situations relating to international law, states operate in a noneconomic market environment, making the selection argument less relevant. Moreover, the application of selection effects to states is difficult, because in contrast to firms, states are never formally eliminated from international relations and do not incur losses in the same way that firms might be pushed out of the market-states can fail, but they do not liquidate. ${ }^{80}$ Finally, even with respect to firms active in economic market contexts, empirical behavioral research has shown that while competitive forces do tend to eliminate some boundedly rational firms, they also "inevitably select some other such actors for success," to the point that firms that are imperfectly rational in their behavior even become overrepresented among surviving and successful corporations. ${ }^{81}$

Subject to empirical research on this issue, it would appear that the same might apply as a plausible hypothesis relating to states (i.e., that states do not become more perfectly rational, but rather maintain a degree of boundedness despite the external competitiveness). ${ }^{82}$ But in any case,

\footnotetext{
${ }^{78}$ Posner, supra note 49, at 1570-71.
}

79 Thomas S. Ulen, The Growing Pains of Behavioral Law and Economics, 51 VAND. L. REV. 1747, $175^{8}$ (1998) (conceding that "everyone has problems with intertemporal choice"). But see Donald C. Langevoort, Behavioral Approaches to Corporate Law (suggesting a number of strategies to overcome the problems of applying individual biases to a business setting), in RESEARCH HANDBOOK ON THE ECONOMICS OF CORPORATE LAW 442, 443-45 (Claire A. Hill \& Brett H. McDonnell eds., 2012).

${ }^{80}$ There are a few exceptions. For example, in 1934, the self-governing status of the British Dominion of Newfoundland was suspended due to economic crisis and its inability to pay interest charges on its national debt and replaced by a Commission of Government composed of nonelected civil servants; in 1949, Newfoundland joined the Canadian Confederation. See David Mackenzie, Canada, The North Atlantic Triangle, and the Empire, in 4 THE OXFORD HISTORY OF THE BRITISH EMPIRE: The Twentieth Century 574, 589-92 (Judith M. Brown \& Wm. Roger Louis eds., 1999). However, this likely was not caused by a particular form of rationality in the Dominion's conduct.

${ }^{81}$ Avishalom Tor, The Fable of Entry: Bounded Rationality, Market Discipline, and Legal Policy, 101 MICH. L. REV. 482, 485 (2002).

${ }^{82}$ One important stream of behavioral writing adopts an organizational approach, taking bounded rationality as a significant environmental factor in the firms' decisionmaking. See, e.g., RichaRd M. CyERT \& JAMES G. MARCH, A BEHAVIORAL THEORY OF THE FIRM 99-101 (1963) (arguing that firms are "adaptively rational" systems that learn from their past experience in an unstable and unpredictable environment, and thus the rationality of their decisions will be limited by the "problems of learning," such as the inability to see the full range of choices and 
this discussion does lead to an important methodological qualification. The idea of behavioral international law, so far as it is applied to states, is not simply to lift whatever knowledge we have gained about real individual decisionmaking and plant it willy-nilly on states, in the way that traditional L\&E has often done with assumptions of human rationality. Rather, one goal of the approach would be to seek observable systematic diversions from rationality in state behavior, without simply assuming that those biases and heuristics found in individuals are replicated by states. Indeed, as already noted, behavioral psychology does not claim that all individuals suffer from the same cognitive biases or employ the same decisionmaking heuristics. It would be a travesty to behavioral theory to claim that states simply reproduce particular individual behavioral traits. Thus a behavioral approach to international law could focus on examining the decisions made by states in differing circumstances from a behavioral perspective, rather than simply applying individual behavioral theory to states. For example, one would not simply assume that states qua states have a fairness bias; this would have to be demonstrated empirically. Under this approach, one would maintain the state as the decisionmaking unit and look into the consistency of deviations from rationality apparent in the state's decisional outputs.

The second way of arguing that states might actually overcome both the bounded rationality of individuals (ostensibly undermining recourse to behavioral economic analysis of international law) and their naturally unitary character would be to cut the Gordian knot and look within the state. Perhaps processes taking place within the state perfect its rationality? To be sure, this line of argument would appear to be inherently inconsistent with the way economic analyses of international law have worked so far: with few exceptions, $L \& E$ analyses of international law have accepted the state as a unitary, even monolithic, actor. ${ }^{83}$ But contrary to the assumptions of realist theorists, states do not act like black boxes or billiard balls. Rather,

payoffs available). Elements of this approach have recently been transposed to international relations. See JOSEPH JuPille, WALTER MATtli \& DUNCAN SNidAl, Institutional CHOICE AND GLOBAL COMMERCE 6-7, 22-23 (2013) (advancing the notion that the bounded rationality of states explains why preexisting institutions that are "good enough" persist despite the opportunity to change to "better" institutional arrangements).

${ }^{83}$ The most notable exceptions are Joel P. Trachtman, International Law and Domestic Political Coalitions: The Grand Theory of Compliance with International Law, 11 CHI. J. INT'L L. 127, 154-55 (2010), which argues that a state's decision to comply or not to comply with international law is a result of changes in domestic coalitions caused by the international law, and Joel $\mathrm{P}$. Trachtman, Open Economy Law, in INTERDISCIPLINARY PERSPECTIVES, supra note 14, at 544, 555, in which the author develops a model where domestic lobbying and voting based on preferences are the causal factors for determining states' compliance with international law. 
state behavior with respect to international law is the outcome of intricate social, political, administrative, and legislative processes that take place within the state. Yet, crucially, looking within the state does not negate the subsequent treatment of the state as an actor with individually observable behavioral traits.

Liberalist international relations scholars have long recognized the complex interactions between domestic politics and international relations, through the metaphors of the second image ${ }^{84}$ or the two level game. ${ }^{85}$ For present purposes we are concerned with the question whether behavioral economic approaches can meaningfully be applied to states at the second, international level. Arguably, for bounded rationality (let alone bounded willpower or self-interest) to be manifest at the international game levelin which we ought to include international law constructions and constraints-biases and heuristics must factor in also, and indeed initially, at the domestic game level. There is in fact a substantial body of research and scholarship on the role of bounded rationality in domestic political processes, ${ }^{86}$ as well as public policy and administration. ${ }^{87}$ To the extent that imperfect rationality within the state is a necessary condition for considering states as boundedly rational actors (unitary or non-unitary, depending on one's definitions), it is quite easily satisfied.

This does not, however, remove entirely this argument against applying bounded rationality to the state on the international plane because of intrastate process. All that this scholarship might contribute in the present context is that cognitive biases and heuristics evident in the domestic policy environment may influence the preference formation of the state as an actor on the international level. In this sense, we are here merely confronted with a particular form of thin rationality of states. ${ }^{88}$ Domestic bounded rationality is neither necessary nor sufficient for international behavioral

\footnotetext{
${ }^{84}$ See generally Peter Gourevitch, The Second Image Reversed: The International Sources of Domestic Politics, 32 INT'L ORG. 881 (1978) (examining the effects of international politics on domestic politics and domestic structures on the international system).

${ }^{85}$ See Robert D. Putnam, Diplomacy and Domestic Politics: The Logic of Two-Level Games, 42 INT'L ORG. 427, 434 (1988) (conceiving of international relations as a two-level game, one at the national level and one at the international level).

${ }^{86}$ See, e.g., Herbert A. Simon, Human Nature in Politics: The Dialogue of Psychology with Political Science, 79 AM. POL. SCI. REV. 293, 300 (1985) ("[B]ehavior depends on the structure of the [voters'] utility functions, and ... on their representations of the world in which they live, what they attend to in that world, and what beliefs they have about its nature.").

87 See Bryan D. Jones, Bounded Rationality and Political Science: Lessons from Public Administration and Public Policy, 13 J. PUB. AdMIN. Res. \& THEORY 395, 406-07 (2003) (explaining that a sound explanation of public administrative behavior must focus on informationprocessing and not just principal-agent problems).

${ }^{88}$ See supra text accompanying notes $31-32$.
} 
analysis, although it might play a part. What we might know about the rationality of domestic policy and state preference formulation does not necessarily reflect upon the overall rationality of the state as an actor in pursuit of those preferences in the international environment.

This theoretical uncertainty seems, however, to cut both ways. On one hand, in principle states can be imperfectly rational at the domestic level, yet perfectly rational at the international level. One might even hypothesize that the aggregation of differential bounded rationalities of various agents at the sub-state level produces some sort of perfect rationality of the state in international affairs. On the other hand, bounded rationality might simply carry over to the international plane, whether en banc or in subtle and variegated ways.

We do not really know, in theory or in practice, how bounded rationalities interact with each other at different degrees of contingency, whether horizontally (within the state) or vertically (between the domestic environment and the international level). But this uncertainty only encourages behavioral analysis of international law.

Perhaps more importantly, this discussion shows that the state (whether viewed as unitary or not) is a plausible individual unit to which behavioral economics can be applied, at least under particular informed circumstances-certainly no less so than traditional rational choice and $\mathrm{L} \& \mathrm{E}$ analyses. However, it also demonstrates that there is still much to learn and examine from a behavioral perspective if the state is to be regarded as such a unit of analysis. But we need not resolve these issues entirely; there is no question that sub-state entities, such as decisionmaking collectives and the individual, can also figure significantly in the study of behavioral international law.

\section{Decisionmaking Collectives in International Law}

A second response to the objection based on the individual focus of behavioral analysis would be to eschew state-level analysis, looking instead at the behavioral aspects of collective decisionmaking within states and other relevant entities, such as nonstate actors, international bureaucracies, and tribunals, that lead to outcomes in international law. In other words, no methodological statism would be involved. Rather, this second level of analysis recognizes that states do not make decisions relating to international law; people do-or most often, groups of people do. 
There exists a significant behavioral literature on cognitive biases in small decisionmaking groups. ${ }^{89}$ In particular, there is an important debate on the existence and effects of "groupthink," defined as the set of phenomena in which individuals comprising a decisionmaking group suffer "a deterioration of mental efficiency, reality testing, and moral judgment that results from in-group pressures." ${ }^{90}$ Small-group decisionmaking theories based on behavioral psychology have been applied in international politics (but not law) to decisions such as whether to embark in international interventions. ${ }^{91}$ Prospect theory has also been applied to relevant group decisions, including to foreign policy decisions and bureaucracies. ${ }^{92}$ There are even empirical studies examining the existence of decisionmaking biases in extremely large decisionmaking collectives, such as the U.S. electorate. ${ }^{93}$ In short, there is room to engage seriously in the study of the rationality of choices pertaining to international law at the decisionmaking group level of analysis.

${ }^{89}$ See, e.g., Roland Bénabou, Groupthink: Collective Delusions in Organizations and Markets, 80 REV. ECON. STUD. 429, 438 (2013) (suggesting that a group member has the incentive to deny reality when the member's colleagues are denying reality in a way that is harmful to the group); Norbert L. Kerr, Robert J. MacCoun \& Geoffrey P. Kramer, Bias in Judgment: Comparing Individuals and Groups, 103 PSYCHOL. REV. 687, 696-98 (1996) (demonstrating theoretically that the process by which groups transform individual preferences into group decisions-majority rule, proportionality, or consensus-affects the degree of bias in the group).

${ }^{90}$ IRVING L. JANIS, GROUPTHINK: PSYCHOLOGICAL STUDIES OF POLICY DECISIONS AND FIASCOES 9 (2d ed. 1982); see also PAUL 'T HART, GROUPTHINK IN GOVERNMENT: A STUDY OF SMALL GROUPS AND POLICY FAILURE 5-12 (1990) (clarifying Janis's groupthink as "an excessive form of concurrence-seeking" and delineating three antecedent conditions for it: high cohesiveness of the decisionmaking group, specific characteristics in the group's organizational context, and stressful internal and external characteristics of the situation). But see Glen Whyte, Recasting Janis's Groupthink Model: The Key Role of Collective Efficacy in Decision Fiascoes, 73 ORGANIZATIONAL BEHAV. \& HUM. DECISION PROCESS 185, 194-97 (1998) (suggesting that it is not group cohesiveness, but high collective efficacy, or the "illusion of invulnerability," which leads to groupthink symptoms, because it causes decisionmakers to perceive all choices as between maintaining an unacceptable status quo-"a sure loss"-or taking an action that if unsuccessful will lead to a greater loss but if successful will yield great gains).

${ }^{91}$ See VERTZBERGER, supra note 38, at 90-99 (surveying how social interaction affects a group's ability to perceive and tolerate risk in four ways: by diluting each individual group member's responsibility for a risky decision; by allowing more resolute members, who are usually risk-tolerant, to persuade others; by facilitating the exchange of information that often leads members to be more confident in their positions; and by revealing each group member's risk tolerance).

92 See generally ROSE MCDERMOTT, RISK-TAKING IN INTERNATIONAL POLITICS: PROSPECT THEORY IN AMERICAN FOREIGN POLICY (1998).

${ }^{93}$ See Adam J. Berinsky \& Jeffrey B. Lewis, An Estimate of Risk Aversion in the U.S. Electorate, 2 Q. J. POL. SCI. 139, 145-47 (2007) (concluding that American voters do not appear risk averse because uncertainty about a candidate's policy position did not cause a statistically significant loss in the expected utility of voting for the candidate). 
Analogies from corporate law are again illuminating, mutatis mutandis. For example, studies have shown that in some circumstances, lawyers practice herd behavior that results in the persistence of suboptimal provisions in bond indentures. ${ }^{94}$ Such reliance on inherited status quo, precedent, and group wisdom might be a response to individual bounded rationality, which could be countered by responsible board governance. ${ }^{95}$ It is not difficult to conceive research questions and testable hypotheses relating to similar occurrences of legal groupthink with respect to international law. For example, to what extent do legal advisors engaged in considering new international commitments, such as in the areas of climate change or trade agreements, rely on the legal status quo, instead of exercising their independent judgment on the best possible solutions?

There are also studies that identify groupthink in collective corporate decisionmaking as a catalyst for unethical decisions that would not have been made individually and link the lack of diversity in corporate management to illegal acts by corporations. ${ }^{96}$ It would be illuminating to examine decisions by executive decisionmaking groups and governmental legal counsel to authorize acts that violate international law, such as some armed attacks or torture authorizations. ${ }^{97}$

To be sure, looking into the state or within organizations and other collective units interacting with international law in this way could bring us back to the claim that behavioral traits observable at the individual level wash away at the collective level. Here the argument would be that internal decisionmaking settings have a corrective effect on individuals' bounded rationality, leading to more perfect rationality in decisions made at the

\footnotetext{
${ }^{94}$ See Marcel Kahan \& Michael Klausner, Path Dependence in Corporate Contracting: Increasing Returns, Herd Behavior and Cognitive Biases, 74 WASH. U. L.Q. 347, 355-56 (1996) (suggesting that "herd behavior" explains the adoption of standard contract terms even when customized terms would have greater expected value because a lawyer suffers more reputational harm if a failed contract contains customized terms than if it contains standard terms that many other lawyers have used in similar contexts).

${ }^{95}$ See Stephen M. Bainbridge, Why a Board? Group Decisionmaking in Corporate Governance, 55 VAND. L. REV. 1, 28-29 (2002) (proposing that if group decisionmaking reduces the information asymmetries among group members, a member will have less incentive to "herd," or simply follow the ideas of presumably better informed colleagues).

${ }^{96}$ See Anthony J. Daboub et al., Top Management Team Characteristics and Corporate Illegal Activity, 20 ACAD. MGMT. REV. 138, 157 (1995) (suggesting that homogeneity within a "top management team" increases pressures for conformity); Ronald R. Sims, Linking Groupthink to Unethical Behavior in Organizations, 11 J. BUS. ETHICS 651, 654 (1992) (asserting that groupthink causes directors to overvalue each other's approval and discount the ethical concerns of those outside the group).

${ }^{97}$ Thus, one wonders to what extent groupthink and other behavioral phenomena enabled the advice provided by U.S. Department of Justice lawyers relating to torture. See generally Jens David Ohlin, The Torture Lawyers, 51 HARV. INT'L L.J. 193 (2010).
} 
leadership level. To illustrate, there are indications that within business corporations, individuals who are relative risk-takers and less prone to lossaversion rise disproportionately to corporate leadership echelons; it could follow that the corporate decisions made by the decisionmaking groups composed of these individuals are more in keeping with perfect rationality. ${ }^{98}$ If similar selection effects were shown to exist in parliamentary politics or in military command promotions, this could have significant implications for understanding the rationality of group decisions in international law, in that they might actually have a relatively low level of biases and heuristics. Indeed, the result might even be that in some cases decisionmaking groups are more rational than individuals, to some extent vindicating traditional rational choice. ${ }^{99}$

These are, however, only hypotheses and examples. The application of behavioral approaches to collective decisionmaking is far from simple. Even in economic fields, such as corporate and antitrust law, attempts to explore the impacts of cognitive biases on firm-level decisions have been few and far between. At this stage, the important point is that behavioral research on international law can be meaningfully conducted at this level of analysis, setting aside the individual methodology objection to a behavioral approach to international law.

\section{The Individual as a Subject and Decisionmaker in International Law}

A third response to the individualist methodological objection would be to simply focus on individual decisionmaking that relates to international law. The place of the individual is no longer in question or "prospective," as it was half a century ago. ${ }^{100}$ In classical international law, individual actions may be attributed to the state, giving rise to state responsibility under various circumstances, ${ }^{101}$ and so analyses of individual

\footnotetext{
${ }^{98}$ See Donald C. Langevoort, Heuristics Inside the Firm: Perspectives from Behavioral Law and Economics (positing that since promotion decisions are made based on observable results rather than unobservable innate skill of the candidates, successful risk-taking candidates who produce the highest results will be promoted), in HEURISTICS AND THE LAW, supra note 50, at 87, 93.

${ }^{99}$ For a model that attempts to prove this, see Andrew Farkas, Evolutionary Models in Foreign Policy Analysis, 40 INT'L STUD. Q. 343, 351, 355 (1996), which hypothesizes that selection effects, where the group member who recommends successful policies gains influence in the next round of decisionmaking, leads to an increase in the rationality of group decisions over time.

${ }^{100}$ See Ian Brownlie, The Place of the Individual in International Law, 50 VA. L. REV. 435, 435 (1964) ("[T]he individual's 'place' on the stage of world law remains generally diverse and, on the whole, prospective in nature.").

${ }^{101}$ JAMES CRAWFORD, THE INTERNATIONAL LAW COMMiSSION'S ARTICLES ON STATE RESPONSIBILITY: INTRODUCTION, TEXT AND COMMENTARIES 121 (2002) ("In many cases, the
} 
behavior are important for understanding state behavior. Put differently, many cases of compliance or noncompliance with international law are ultimately made by individuals, such as soldiers in the field, immigration officers, customs officials, and legal advisors. Moreover, in modern international law, individuals are increasingly direct addressees and beneficiaries of international law, especially in the areas of investment protection, international human rights, international criminal law, and international humanitarian law, the last constituting an area with major scope for behavioral research, as will be discussed in the next subsection. In addition, some state-to-state law takes into account, or is premised on, assumptions about private behavior, such as the World Trade Organization's goal of "providing security and predictability" to traders. ${ }^{102}$

The point need not be belabored here: behavioral analysis of international law is not restricted to unitary state behavior. There is a rich field of international legal issues that can be examined at the level of individual behavioral economics, in addition to the state level and group decisionmaking levels, whose application is more complex but with the potential to be at least as illuminating.

\section{B. The Empirical Foundations of Behavioral Theory}

It is perhaps the crowning achievement of behavioral analysis of law that it is based on claims about human behavior that are empirically substantiated. Some go so far as to say that "legal scholarship not drawing on empirical behavioral findings is not engaged in a behavioral analysis of law." ${ }^{103}$ If the behavioral approach's predictions about actors' actions in the face of legal prescriptions are more dependable and realistic than those of standard rational choice theory with all its explanatory strengths, it is because of the behavioral approach's empirical, and more so, experimental, basis. In this respect, an objection could be raised toward a behavioral approach to international law: that the empirical-and especially experimental-insights and methods of behavioral analysis are difficult, if not impossible, to apply to international law.

Clearly, there are methodological difficulties in applying an experimental empirical approach to international law. At the state level, one

conduct which is acknowledged and adopted by a State will be that of private persons or entities.").

${ }^{102}$ Understanding on Rules and Procedures Governing the Settlement of Disputes art. 3.2, Apr. 15, 1994, Marrakesh Agreement Establishing the World Trade Organization, 1869 U.N.T.S. 404.

\footnotetext{
${ }^{103}$ Tor, supra note 51 , at 273.
} 
cannot conduct experiments. At the group decisionmaking level, access to actual decisionmaking groups and senior decisionmakers is normally limited for most researchers. Experimental research with individuals also poses significant challenges. Access to real international law decisionmakers such as trade officials or military commanders for experimental purposes is also constrained. Even if achieved, it would be difficult to design experiments that replicate the real-life environment of decisionmaking. However, this objection merely underscores the nonempirical basis of most international legal research. Recent years have witnessed a growing cadre of legal scholars who apply quantitative and qualitative empirical research methods to international law. ${ }^{104}$ Nonbehavioral empirical research of international law encounters many of the same difficulties that behavioral research of international law would be faced with, and copes with them successfully.

There are, in fact, a number of ways in which behavioral analysis could be meaningfully applied to international law, on the basis of empirical findings, experimental or not. In this sense, a behavioral approach to international law is no different than general behavioral legal research. Following Tor's useful menu for research, ${ }^{105}$ behavioral insights on the law can be gained through three complementary channels: (1) theoretical applications, (2) experimental research, and (3) field studies. The strengths and weaknesses of each methodology should be recognized, but each of them retains an empirical basis and could be applied to different

104 See, e.g., Gregory C. ShAFFER, DEFEnding InTERESTs: Public-Private PARTNERSHIPS IN WTO LITIGATION (2003) (using WTO data to determine the social, political, and legal implications for the U.S. and European approaches to public-private networks in international governance); Marc L. Busch \& Krzysztof J. Pelc, Ruling Not to Rule: The Use of Judicial Economy by WTO Panels (using data from WTO panel reports to analyze the relationship between mixed submissions and the exercise of judicial economy), in THE POLITICS OF INTERNATIONAL ECONOMIC LAW 263, 276 (Tomer Broude, Marc L. Busch \& Amelia Porges eds., 2011); Susan D. Franck, Empiricism and International Law: Insights for Investment Treaty Dispute Resolution, 48 VA. J. INT'L L. 767, 784 (2008) (finding that “international economic law has tangible international law obligations in treaties, and there is associated data that are ripe for empirical analysis"); Oona A. Hathaway, Why Do Countries Commit to Human Rights Treaties?, $51 \mathrm{~J}$. CONFLICT RESOL. 588, 598 (2007) (using "a hazard analysis to test the strength of the specific predictions regarding states' willingness to commit to human rights treaties"); Krzysztof J. Pelc, Googling the WTO: What Search-Engine Data Tell Us About the Political Economy of Institutions, 67 INT'L ORG. 629, 631 (2013) (relying on search-engine data to analyze behavioral reactions to violations of international law). For an overview, see generally Gregory Shaffer \& Tom Ginsburg, The Empirical Turn in International Legal Scholarship, 106 AM. J. INT'L L. 1 (2012).

${ }^{105}$ See Tor, supra note 51, at 272-91 ("A review of extant scholarship in the behavioral approach as defined here reveals two distinct, albeit closely related, methodological genes. The more common involves theoretical applications of behavioral evidence generated by non-legal, empirical, scholarship. Its rarer but important counterpart genre conducts direct empirical, mostly experimental, tests of legally relevant questions."). 
international legal puzzles, showing that this objection is definitely not one that can stop behavioral analysis of international law at the threshold.

\section{Theoretical Applications}

Theoretical applications take research scenarios in which a divergence from perfect rationality is noted on the basis of general empirical evidence, and then apply the ramifications to a legal rule or institution. The application is theoretical in the sense that although it is empirically valid in one area, it is being applied in a different legal field and set of circumstances; hence, empirical authority is reduced. This migrational methodology will be familiar to most interdisciplinary legal scholars: theoretical knowledge from non-legal fields is adopted and applied to legal issues; empirical knowledge from one field of law migrates to another. In international legal research, theoretical application could also include cases in which insights from behavioral economics in other areas of law are applied to international law, or instances in which nonlegal IR research on behavior of states and other actors has international legal implications.

For example, theoretical applications of cognitive psychology challenge the traditional rational choice parameters of deterrence in criminal law ${ }^{106}$ by suggesting (among other points) that optimism or overconfidence biases could cause potential offenders to underestimate the probability that they will be apprehended and convicted. Moreover, the availability bias might mean that visibly increased enforcement has a greater effect on deterrence than increased punishment. ${ }^{107}$ These are both theoretical applications of general expressions of bounded rationality to a legal issue, with implications for criminal enforcement policy. Given that a central goal of international criminal justice is deterrence and prevention of future international crimes by punishing existing ones, ${ }^{108}$ any theoretical

${ }^{106}$ See Gary S. Becker, Crime and Punishment: An Economic Approach, 76 J. POL. ECON. 169, 180 (1968) (describing the deterrence parameter as a function of $p$, the probability of conviction, and $f$, the punishment).

${ }^{107}$ Jolls, supra note 70 , at 277 (suggesting that availability bias predicts that potential parking violators would be more likely to be deterred if the risk of receiving a parking ticket was more salient and vivid).

${ }^{108}$ Julian $\mathrm{Ku} \&$ Jide Nzelibe, Do International Criminal Tribunals Deter or Exacerbate Humanitarian Atrocities?, 84 WASH. U. L. REV. 777, 787 (2006) ("The deterrence rationale for [international criminal tribunals] usually takes the form of a generalized argument in favor of justice for perpetrators of humanitarian atrocities and in opposition to impunity and realpolitik."); Otto Triffterer, The Preventive and Repressive Function of the International Criminal Court, in The Rome Statute of the InTERnational CRiminal CourT: A CHALlenge to IMPUNITY 137, 144 (M. Politi and G. Nesi eds., 2001); see also Invited Experts on Prevention Question, ICC FORUM, http://iccforum.com/prevention (last visited Feb. 27, 2015), archived at 
application of behavioral psychology to criminal law would by extension be relevant to international criminal law.

However, this example demonstrates the main weakness of theoretical application as a methodology: the external validity challenge, which creates and augments the difficulty in transferring empirical findings from one research group to another group that differs from the first in its personality and environment. ${ }^{109}$ To what extent can behavioral traits established in experimental research among college students under laboratory conditions be applicable to criminals? To what extent can theories applied to criminals in the setting of domestic law and society be reapplied to potential war criminals acting in very different circumstances and under very different utility functions? When the external validity-or generalizability-of behavioral inferences is questionable, theoretical applications can still be highly useful because they have the ability to generate interesting hypotheses. However, these hypotheses would then need to be tested against relevant empirical evidence through field studies or experimental research. To be sure, this will not always be possible, in which case the behavioral insights should be understood as bearing reduced research value, but not less than that of nonempirical methods.

\section{Experimental Research}

Experimental behavioral legal research entails controlled and randomized experiments in which participants' reactions to different treatments in legal settings are polled and statistically compared, within experimental and control groups. This allows the researcher "to draw conclusions about the causal effects of the experimental treatment." ${ }^{110}$ For example, groups of randomly selected students can be asked to play the role of trial jurors and to answer certain questions with different fact patterns. In international legal issues, the same groups could be asked to pose as individuals in combat settings with respect to rules of international humanitarian law, or as regular citizens with respect to human rights issues.

While the strength of experimental research lies in its controlled and randomized environment, this is also the source of its weakness. Again we are faced with the problem of external validity. Both the subjects and the

\footnotetext{
http://perma.cc/T7QX-NUCJ (summarizing expert opinions on the question of the role of the International Criminal Court in crime prevention).

${ }^{109}$ See Tor, supra note 51, at 280 ("Th[e] [external validity] problem concerns the validity of inferences about whether the ... effect... holds over variations in persons, settings, treatment variables, and measurement variables." (internal quotation marks omitted)).

${ }^{110} \mathrm{Id}$. at 285 .
} 
circumstances are very different from those that govern in reality. Although there is evidence that behavioral simulations and surveys, properly conducted, can provide reliable evidence that conforms to results from the field, ${ }^{111}$ experimental research is often treated with suspicion in the social sciences as lacking in its realism and generalizability. ${ }^{112}$ Nevertheless, some scholars contend that most of the objections to experimental research are misguided and that more experimental social science research should be conducted as a significant complement to and corroboration of field research. ${ }^{113}$ Behavioral legal research-certainly with respect to international law-faces similar dilemmas; but ultimately, their resolution will depend on the ability to conduct meaningful experimental research on particular research questions, and researchers should take cognizance of this in both their selection of research topics and in the design of experiments. For example, experimental studies relating to international humanitarian law or trade law can be upgraded by conducting controlled experiments with groups of relevant decisionmakers, such as military commanders and trade officials and executives, respectively. ${ }^{114}$

\section{Field Studies}

Experimental research is not the only way to gather empirically valid information about the way people make decisions. Indeed, some consider field research, which uses observational testing of real behavior, to be the first-best method. A significant criticism leveled at the behavioral L\&E movement is that knowledge gleaned from experiments is limited in its ability to provide guidance for real life policy because it lacks context, and

${ }^{111}$ Craig A. Anderson, James J. Lindsay \& Brad J. Bushman, Research in the Psychological Laboratory: Truth or Triviality?, 8 CURRENT DIRECTIONS PSYCHOL. SCI. 3, 8 (1999) ("The obvious conclusion from Figure 1 is that the psychological laboratory is doing quite well in terms of external validity ....").

${ }^{112} I d$. at 3 (summarizing the opposing view that "research from the psychological laboratory is extremely invalid, and therefore pointless").

${ }^{113}$ See, e.g., Armin Falk \& James J. Heckman, Lab Experiments Are a Major Source of Knowledge in the Social Sciences, 326 SCI. 535, 537 (2009) ("Experiments can be productive in complementing the information obtained from other empirical methods. One can combine lab and field experiments to better understand the mechanisms observed in the field.").

${ }^{114}$ Notably, international relations scholars have recently turned to experimental research, some of it relating to international law. See Alex Mintz, Yi Yang \& Rose McDermott, Experimental Approaches to International Relations, 55 INT'L STUD. Q. 493, 494-98 (2011) (describing five types of experiments used in international relations); see also Hafner-Burton et al., supra note 72 (manuscript at 4-5) ("By studying both populations using identical experimental instruments we explore not just how behavioral traits relate to policy preferences for trade cooperation but also help reveal how non-elite samples may differ from real policy elites."). 
should be at least supplemented by field observations. ${ }^{115}$ However, observational testing of behavioral questions in legal contexts is still rare. ${ }^{116}$ In this respect, international legal research might actually have significant strengths. At the state level of analysis, the relevant research group for observational field research is limited to under 200 entities, with a vast historical background for research. This can foment quantitative research, in fields such as international litigation, which although on the rise is still much easier to track in terms of volume than the domestic judicial activity of even a small state. Qualitative empirical research is quite developed, such as in international political economy. One can glean a lot of information on decisionmaking processes ${ }^{117}$ given this long historical memory. ${ }^{118}$ Quantitatively, international relations researchers have already compiled historical databases that can be relevant to ex post observational testing of legal issues; one example is the Correlates of War (COW) project. ${ }^{119}$ Field studies at the individual level are difficult but possible. ${ }^{120}$

In sum, there is no a priori reason to discard the idea of conducting empirical behavioral research in international law. Instead, it is quite the contrary: such research can be conducted in all three methodological streams (theoretical application, experimental research and field studies) in meaningful ways.

\section{The Parsimony of Traditional Concepts of State Rationality}

The final general objection to a behavioral approach to international law would be that its high degree of contingency-on actors, environments, and levels of analysis - would make it unparsimonious, in contrast with the parsimony that characterizes traditional economic or rational choice

\footnotetext{
${ }^{115}$ See Tanina Rostain, Educating Homo Economicus: Cautionary Notes on the New Behavioral Law and Economics Movement, 34 LAW \& SOC'Y REV. 973, 1002-03 (2000) ("Legal scholarship that seeks to incorporate the insights of empirical social science must be aware of the limitations of such knowledge. Before laboratory results can serve as the basis for legal policy, they must be replicated in field studies that resemble as closely as possible 'natural' conditions. And proposed interventions must be tried in small-scale pilot studies before they are implemented broadly.").

${ }^{116}$ See Tor, supra note 51, at 281 ("Observational tests of legal questions have become increasingly popular in recent decades, although still relatively uncommon compared to traditional legal scholarship.").

${ }^{117}$ See supra note 104.

${ }^{118}$ See, e.g., Barbara Farnham, Roosevelt and the Munich Crisis: Insights from Prospect Theory, 13 POL. PSYCHOL. 205, 225 (1992) (applying prospect theory to an analysis of President Roosevelt's behavior in the Munich hostage crisis).

119 See CORRELATES WAR, http://www.correlatesofwar.org (last visited Feb. 27, 2015), archived at http://perma.cc/Q 33 B-7TRS

${ }^{120}$ See Fellmeth, supra note 6, at 134-35 (recognizing criticisms of previous studies for failing to collect actual battlefield data and undertaking a study of state practice).
} 
analyses of law and international relations. This is certainly true; indeed, experimental literature has over time discovered so many cognitive biases, sometimes contradictory, that it is dangerous to make generalizations in research. This critique would not, however, be unique to international behavioral analysis, and the response provided by behavioralists would apply here as well. The parsimony achieved through rational choice theory comes at the expense of empirical accuracy and predictive power. ${ }^{121}$ Ideally, one should have both parsimony and accuracy. But ultimately, so long as such an approach is not at hand, whether one prefers one method or another is very much a question of both intellectual temperament and the balance between accuracy and parsimony-how much of one is sacrificed for the sake of the other. There would seem to be little to add to this debate, but I would venture the following. A behavioral approach to international law would not-and should not-underwrite a claim to providing a theory of everything or even a theory of international law. It would simply be an addition to the arsenal of methodologies of international law, like rational choice or sociological approaches, applicable and illuminating in some contexts, less so in others. Within the bounds of those discrete areas in which it is both illuminating and intellectually honest, it would be parsimonious, although parsimony should not be confused with simplicity. So, for example, if behavioral research would show that military field commanders do not currently or usually take the remote possibility of international criminal prosecution as a consideration in their operative calculations, but in contrast are deterred by domestic (and more "available") sanctions, such as investigations by committees of inquiry and demotions, this specific finding would in itself be parsimonious, as well as empirically accurate. Therefore, the risk of a lower degree of parsimony in behavioral analysis is a methodological constraint to consider in the design of research, but it is not a threshold barrier to it.

\section{SOME INDICATIVE APPLICATIONS OF BEHAVIORAL RESEARCH TO INTERNATIONAL LEGAL ISSUES}

So far, potential uses of behavioral research on international law have been mentioned only in passing. In this Part, I will describe in more detail select indicative applications of behavioral international research. By no means should this discussion be mistaken for actual behavioral research.

\footnotetext{
${ }^{121}$ See Jolls, Sunstein \& Thaler, supra note 47 , at 20-21 ("[T]o the extent that conventional economics achieves parsimony, it often does so at the expense of any real predictive power."); see also Elms, supra note 33, at $240-42$ (examining the role played by behavioral economics and political psychology in economic decisionmaking).
} 
Rather, it comprises a set of prototypical research briefs and proposals, which indicate in concrete yet general terms how behavioral research projects could be conducted with respect to international legal questions. It is a methodological tasting menu, an invitation for research. To be sure, as noted above, there exist already some very thoughtful first buds of such research.

The research issues discussed below have been selected so as to allow for the full range of applicable levels of analysis (the state, small decisionmaking groups, and individuals) discussed above in Section III.A, and the full spectrum of behavioral research methods (theoretical application, experimental research, and field studies) discussed in Section III.B. They have also been selected to display both explanatory and normative avenues of research and the ways in which behavioral research can be either linked to rational choice frameworks or disengaged from them. Finally, they cover a broad range of international legal issues, from general international law and dispute settlement to international economic and humanitarian law. The queries addressed are: (A) how can international treaty-making be made more efficient?; (B) do collegial international tribunals produce better outcomes than non-collegial ones?; and (C) should international humanitarian law relating to target selection in armed conflict take into account the bounded rationality of military commanders and decisionmakers?

\section{A. The State Level: The Efficiency of International Law-Making and the Status Quo Bias}

When can international lawmaking be deemed efficient? L\&E scholars have over the last decade or so devoted copious attention to explanations of international lawmaking processes, especially their two central sources: treaties and customary international law. ${ }^{122}$ A subset of this literature criticizes international lawmaking as inefficient. In particular, scholars have argued that international law does not adapt quickly or reflexively enough to the preferences of states and the needs of the global community. Thus, for example, international legal responses to global warming and

\footnotetext{
${ }^{122}$ See Goldsmith \& Posner, supra note 23, at 1116-20 (discussing the origins of, compliance with, and evolution of customary international law); Andrew T. Guzman, Saving Customary International Law, 27 MICH. J. INT'L. L. 115, 131-75 (2005) (outlining a theory of customary international law rooted in rational choice); George Norman \& Joel P. Trachtman, The Customary International Law Game, 99 AM. J. INT'L L. 541, 544-73 (2005) (presenting a rationalist model of customary international law); see also Laurence R. Helfer, Exiting Treaties, 91 VA. L. REV. 1579, 1601-10 (2005) (discussing nations' adoption of and exit from international treaties).
} 
transnational terrorism remain blocked. ${ }^{123}$ In this Section, I will focus on a particular critique of the efficiency of treaty formation, setting aside discussion of critiques relating to customary international law as such. ${ }^{124}$

With respect to treaty law, Guzman has argued that the chief cause for lack of progress toward effective global legal solutions is in many cases international law's strict requirement of consent in treaty-making: ${ }^{125}$ states may be bound by treaty norms only if they have expressly consented to them. ${ }^{126}$ Hence, so long as some states can object to new treaty arrangements or to reforms of existing ones solely on the basis of their narrow self-interest, they can prevent legal responses that satisfy the collective interests of the international community. According to Guzman, the consent requirement should be relaxed in ways that would enable the global community to create law that would bind states non-consensually. ${ }^{127}$

What is most important for present purposes, however, is that Guzman's analysis builds on understandings of efficiency that lie firmly within the standard economic approach to contract law. This approach regards private contracts as efficient in the Coasean sense: bargaining among parties will lead to an allocation of rights and obligations that optimizes their preferences, regardless of initial allocations, provided that transaction costs are at zero or are very low. ${ }^{128}$ The economic model of contract law can be similarly extended to international treaties. States, considered as unitary actors, enjoy substantial freedom in the pursuit of their interests through bilateral and multilateral treaty-making, in a manner reminiscent of the private ordering achieved through the freedom of

\footnotetext{
${ }^{123}$ See supra notes 1-3 and accompanying text (examining the lack of treaty or customary international law solutions to problems such as global warming or terrorism).

${ }^{124}$ See GuZMAN, supra note 7, at 170-71 (discussing efficiency considerations involved in membership in international agreements); see also Curtis A. Bradley \& Mitu Gulati, Withdrawing from International Custom, 120 YALE L.J. 202, 208-15 (2010) (discussing the relationship between international treaties and customary international law); Eugene Kontorovich, Inefficient Customs in International Law, 48 WM. \& MARY L. REV. 859, 895-906 (2006) (exploring the efficiency of customary international law).

${ }^{125}$ Andrew T. Guzman, Against Consent, 52 VA. J. INT’L L. 747, 751 (2012).

${ }^{126}$ See LOUis Henkin, 18 InTERnational LAW: Politics AND VAlues 28 (1995) ("No treaty, old or new, whatever its character or subject, is binding on a state unless it has consented to it."); see also Vienna Convention on the Law of Treaties art. 2.1(g), art. 34, May 23, 1969, 1155 U.N.T.S. $33^{1}$ (defining a "party" to a treaty as a State that has consented to be bound by it and unambiguously providing that "[a] treaty does not create either obligations or rights for a third State without its consent").

127 In particular, Guzman advocates for increased use of nonconsensual rulemaking procedures in international organizations, though stopping short of "limitless delegation of authority." See Guzman, supra note 125, at 789-90.

${ }^{128}$ ROBERT COOTER \& THOMAS UlEN, LAW \& ECONOMICS 85 (6th ed. 2012).
} 
contract in domestic legal settings. ${ }^{129}$ From a rational choice perspective, this can lead to welfare analyses familiar from contract theory, such as efficient breach. ${ }^{130}$

Thus, where treaty obligations are entered into on an informed and voluntary basis, rational choice models generally assume that international multilateral rules are efficient with respect to parties' preferences, at least at the time that these obligations are made. The classical Paretian formulation posited by Trachtman states in this respect that "[i]n the cooperative treaty game, any treaty must be such that, at least in prospective terms, each adherent receives a benefit that is at least as great as it would receive if it did not join in the treaty." ${ }^{131}$ As Guzman explains, a Pareto-efficient improvement in treaty law (whether reforms to an existing treaty regime or the launch of a new one) would entail that at least some parties gain from it, but none are made worse off by it (compared with the prevailing legal situation prior to the change). ${ }^{132}$ In contrast, a Kaldor-Hicks efficient treaty improvement would be such that the benefit granted to some states from the change would be greater than the disadvantage caused to other states; in other words, aggregate utility is increased, although there are winners and losers in a distributive sense. ${ }^{133}$ To Guzman, the strict consent requirement in international lawmaking epitomizes a Pareto concept of efficiency; aggregate welfare is sacrificed to the maintenance of individual state welfare. ${ }^{134}$

There are several difficulties with this analysis, but let me focus on one that highlights the possible theoretical application of insights from behavioral economics. Guzman's compelling analysis against consent assumes first that states will, as a rule, agree to changes in treaty law if they benefit from them or at the very least do not suffer from them (Pareto efficient treaty reform) or if they are counted among the winners from a

129 See Michael J. Trebilcock, The Limits of Freedom of Contract 244 (1993) (" $[\mathrm{I}] \mathrm{f}$ two parties are to be observed entering into a contract, one should normally presume that they would not have done so unless they felt that the contract was likely to make them better off.").

${ }^{130}$ See, for example, discussion of ex post "efficient breach" with respect to international treaties in Trachtman, supra note 7, at 142-44. See also ROBERT E. SCOTT \& PAUL B. STEPHAN, THE LIMITS OF LEVIATHAN: CONTRACT THEORY AND THE ENFORCEMENT OF INTERNATIONAL LAW 84-109 (2006) (advancing the "optimal enforcement" theory of international law); Eric A. Posner \& Alan O. Sykes, Efficient Breach of International Law: Optimal Remedies, "Legalized Noncompliance," and Related Issues, 110 MICH. L. REV. 243, 246-64 (2011) (discussing the concept of "efficient breach" in the context of international treaties).

${ }^{131}$ TRACHTMAN, supra note 7 , at 128 .

${ }^{132}$ Guzman, supra note 125 , at 758 .

${ }^{133} \mathrm{Id}$.

${ }^{134} \mathrm{Id}$. 
Kaldor-Hicks efficient treaty change. In the face of these rationality-based assumptions, cognitive psychology provides a startling insight: all things considered, people actually have a tendency to prefer an existing state of affairs over alternatives that might leave them better off. This is referred to as the status quo bias. Experiments with individuals show that they disproportionately prefer the status quo over alternatives when making decisions: "Faced with new options, decision makers often stick with the status quo alternative, for example, to follow customary company policy, to elect an incumbent to still another term in office, to purchase the same product brands, or to stay in the same job." ${ }^{135}$ This phenomenon is conceptually related to the endowment effect, in the sense that people view the existing state of affairs as an endowment that they value more than possibly improved conditions, which they associate with risk and uncertainty.

The status quo bias has distinct implications for the development of legal systems and arrangements, both domestic and international. Generally, it suggests that contracts will be inherently "sticky" and inefficient because agents prefer to keep the law as it is, even when the law lags behind changes in their otherwise rational interests and preferences, and even in the face of personal, commercial, or other developments. ${ }^{136}$

A more advanced application of the status quo bias relates to default rules-rules that apply in the absence of a specific agreement to apply different rules. Coasean economics predicts that default rules-the initial legal arrangement-will not affect bargained contractual arrangements, unless precluded by transaction costs, and so their effect in real legal relations is minimal. Yet experimental research conducted among private contractors has confirmed the status quo bias and shown that default rules matter; there is a tendency to adopt them in negotiated settings, even if they are inefficient. Thus, default rules are not just a fallback when certain issues are left open in contracts; they have an effect on negotiated contracts as well. These phenomena have been observed not only in relation to default rules established by law but also with respect to standard form or boilerplate terms that are not ex ante binding upon parties. ${ }^{137}$

${ }^{135}$ William Samuelson \& Richard Zeckhauser, Status Quo Bias in Decision Making, 1 J. RISK \& UNCERTAINTY 7, 8 (1988).

${ }^{136}$ For a survey of evidence of status quo bias and an application to contract law, see generally Russell Korobkin, The Status Quo Bias and Contract Default Rules, 83 CORNELL L. REV. 608 (1998).

${ }^{137}$ See id. at 630-33; see also Russell Korobkin, Inertia and Preference in Contract Negotiation: The Psychological Power of Default Rules and Form Terms, 51 VAND. L. REV. 1583, 1587-88 (1998) ("Th[e] preference for default terms is evident even when transaction costs of contracting around the default are very low and there is no strategic advantage in choosing not to contract around the default."). 
What does this imply for the critique of the strict consent requirement's efficiency in treaty-making? The immediate implication is that states might regularly withhold consent from new treaty regimes and treaty reforms, not only because they believe these regimes and reforms run counter to their best interests, but because of an embedded behavioral aversion to change.

Thus, where Guzman sees the consent requirement as the cause for an observed status quo bias in international treaty law, ${ }^{138}$ it might be that the "excessive commitment to consent" ${ }^{\text {"139 }}$ that he decries is in fact the formal result of a behavioral status quo bias. States preserve the constraints of the consent requirement because it enables them to pursue their (imperfectly rational) preference for status quo. In some respects this makes the critique even stronger because it indicates that the consent requirement may even facilitate the scuttling of treaty regimes and reforms that would be Paretoefficient (i.e., when no state has a rational reason to object), not just those that are Kaldor-Hicks efficient. Treaty reform can therefore be exceedingly difficult even when everybody stands to gain.

The policy implications of this theoretical application are that relaxing the consent requirement would not be sufficient to solve the problem. In many cases, states will still eschew formal legal change. Even in majoritarian and institutional rulemaking settings in international organizations, states might prefer to maintain the rulemaking status quo of consent, despite the existence of alternative formal possibilities. A living example is the World Trade Organization (WTO). Although the WTO's institutional provisions allow for various forms of majority decisionmaking, including amendments to the substantive treaties, ${ }^{140}$ members rarely resort to these provisions, and a culture of consensus continues to govern decisionmaking. ${ }^{141}$

Beyond merely refining the critique of consent, acknowledging behavioral status quo bias in treaty-making among states also gives rise to interesting research questions and hypotheses that might be examined empirically. For example, better knowledge of the real incidence and impact

${ }^{138}$ It appears that Guzman intends the term in a colloquial rather than behavioral sense. See Guzman, supra note 125 , at 790 ("The overcommitment to state control over events creates a suffocating status quo bias that does more harm than good.").

${ }^{139}$ See id. at 749 .

${ }^{140}$ See Marrakesh Agreement Establishing the World Trade Organization arts. IX-X, Apr. 15, 1994, 1867 U.N.T.S. 154.

${ }^{141}$ See Claus-Dieter Ehlermann \& Lothar Ehring, Decision-Making in the World Trade Organization: Is the Consensus Practice of the World Trade Organization Adequate for Making, Revising and Implementing Rules on International Trade?, 8 J. INT'L ECON. L. 51, 55 (2005) (indicating that "the process of decision-making in the WTO is dominated by the practice of consensus"). 
of status quo bias in treaty-making can affect strategies for treaty reform demandeurs. Multilateral treaty law can be developed in at least four ways: (a) negotiations leading to the replacement of existing treaty regimes (e.g., the negotiation of the WTO Agreements as a comprehensive replacement of GATT $^{142}$ and patchwork of associated trade agreements that existed at the time); (b) negotiation of new commitments within an existing treaty regime, as mandatory (or partially mandatory), additional or revised commitments (essentially, treaty amendments like the procedures mentioned above as formally available in the $\mathrm{WTO}^{143}$ and amendments to the International Criminal Court (ICC) Statute ${ }^{144}$ ); (c) optional negotiations (e.g., the additional protocols to the Geneva Conventions ${ }^{145}$ and to the main human rights covenants $\left.{ }^{146}\right)$; and $(\mathrm{d})$ negotiations conducted entirely outside existing substantive treaty regimes (e.g., the recently concluded (but not yet in force) Arms Trade Treaty, which was negotiated within the U.N. but is independent of other arms control conventions ${ }^{147}$ ). Even though the negotiated legal changes would be identical, each of these approaches works with different default rules and environments. A combination of quantitative and qualitative research would show which strategy is more successful in practice (although other explanations beyond status quo bias could be proffered).

\footnotetext{
${ }^{142}$ See generally General Agreement on Tariffs and Trade, opened for signature Oct. 30, 1947, 61 Stat. pts. $5 \& 6,55$ U.N.T.S. 194 .

${ }^{143}$ See supra note 140 and accompanying text.

${ }^{144}$ See Rome Statute of the International Criminal Court, July 17, 1998, 2187 U.N.T.S. 90 (entered into force July 1, 2002). Amendments were adopted during the 2010 review conference, notably with respect to the definition of the crime of aggression. See Jennifer Trahan, The Rome Statute's Amendment on the Crime of Aggression: Negotiations at the Kampala Review Conference, 11 INT'L CRIM. L. REV. 49, 55 (2011) (detailing the amendments to the Rome Statute). The time of entry into effect of these amendments may vary among states party to the Rome Statute; indeed the amendment process includes elements of majority lawmaking. See id. at 85 (highlighting the ultimate decision to allow states to accept amendments by ratification).

${ }^{145}$ See, e.g., Protocol Additional to the Geneva Conventions of 12 August 1949, and Relating to the Protection of Victims of International Armed Conflicts (Protocol I), June 8, 1977, 1125 U.N.T.S. 3 (amending the Geneva Convention to more adequately protect victims of armed conflicts); Protocol Additional to the Geneva Conventions of 12 August 1949, and Relating to the Protection of Victims of Non-International Armed Conflicts (Protocol II), June 8, 1977, 1125 U.N.T.S. 609 (supplementing the Geneva Convention to "ensure a better protection for the victims of those armed conflicts").

${ }^{146}$ See, e.g., Optional Protocol to the International Covenant on Civil and Political Rights, opened for signature Dec. 19, 1966, 999 U.N.T.S. 171 (entered into force Mar. 23, 1976) (exemplifying an optional protocol within a treaty).

${ }^{147}$ See Final United Nations Conference on the Arms Trade Treaty, Mar. 18-28, 2013, Report of the Final United Nations Conference on the Arms Trade Treaty, U.N. Doc. A/CONF.217/2013/2 (Apr. 2, 2013).
} 
Perhaps even more intriguing would be research comparing the willingness of states to contract out, inter partes, from customary international rules, ${ }^{148}$ compared with applicable multilateral treaty rules and various "soft law" sources. ${ }^{149}$ Such a study would not assume the existence of status quo bias, but attempt to establish its existence and compare the relative stickiness of custom, convention, and (nonbinding) soft law as default rules.

Indeed, there is much to consider further regarding behavioral insights on the efficiency of the development of customary international law, ${ }^{150}$ but my limited goal here is to present only selected indicative applications, and these considerations must be reserved for future research.

\section{B. Small Decisionmaking Groups: Judicial Design and Conformity Effects in International Tribunals}

The relatively recent rise of judicialization in international law ${ }^{151}$ provides fertile ground for behavioral studies on international courts as decisionmakers. Psychological research has been applied to domestic judges

148 In principle, states can contract around customary international law: "There is no $a$ priori hierarchy between treaty and custom as sources of international law. However, in the application of international law, relevant norms deriving from a treaty will prevail between the parties over norms deriving from customary law." INST. OF INT'L LAW, PROBLEMS ARISING FROM A SUCCESSION OF CODIFICATION: CONVENTIONS ON A PARTICULAR SUBJECT (1995), available at http://www.idi-iil.org/idiE/resolutionsE/1995_lis_01_en.pdf. This principle does not apply if the customary rules in question are considered to be jus cogens-which permit no derogation. See Vienna Convention, supra note 126, art. 53 ("A treaty is void if, at the time of its conclusion, it conflicts with a peremptory norm of general international law.").

${ }^{149}$ On soft law, see generally Gregory Shaffer \& Mark A. Pollack, Hard and Soft Law, in INTERDISCIPLINARY PERSPECTIVES, supra note 14, at 197.

${ }^{150}$ See, e.g., Bradley \& Gulati, supra note 124, at 252 (arguing that customary international law is inefficient because it is too rigid, pursuant to the mandatory doctrine whereby states cannot legally opt out from a customary rule of international law after it has been formed). Interestingly, where the previously mentioned critique of treaty-formation argued that international law was inefficiently inflexible because it did not allow for non-consensual rules, this critique of customary law calls for states to be released from obligations to which they did not expressly commit. It is not entirely clear what type of efficiency Bradley and Gulati take as their point of reference, but as far as behavioral insights are concerned, one could at least hypothesize that the removal of doctrinal or formal constraints on opt-outs from customary law would not achieve an increase in normative efficiency. A behavioral status quo bias, taking existing customary rules as the default, would lead states to generally retain their normative loyalties. Bradley and Gulati only briefly mention the possibility that psychological factors contribute to the stickiness of customary international law. See id. at 248 n.196 (citing Korobkin, supra note 136). For further discussion of custom as default rules, see Rachel Brewster, Withdrawing from Custom: Choosing Between Default Rules, 21 DUKE J. COMP. \& INT'L L. 47 (2010).

${ }^{151}$ See Shany, supra note 4, at 74-76 (tracking the increased use of courts and the expansion of the court's power in international law). 
as individual decisionmakers ${ }^{152}$ and to courts as small decisionmaking groups, with rich and interesting results. ${ }^{153}$ There is no reason to think that such research methods would not be applicable to international judges and tribunals, or indeed, that research results from the domestic sphere could not carry over, under certain conditions and, mutatis mutandis, to the international domain as well. Behavioral research thus may hold significant implications for the design of courts and tribunals. ${ }^{154}$

As an example, consider the ongoing debate regarding the desirability of dissenting opinions in the WTO. The WTO dispute settlement system, entailing state-to-state litigation relating to international trade law, is one of today's most active international tribunals. Disputes are addressed by ad hoc panels and may be appealed to the standing Appellate Body. ${ }^{155}$ Dissenting or separate opinions are allowed, subject to certain formal rules and practices, including a requirement that the dissenter remain anonymous. ${ }^{156}$ Such opinions are, however, formally discouraged ${ }^{157}$ and are in fact very rare. ${ }^{158}$

\footnotetext{
${ }^{152}$ See, e.g., Dan Simon, Freedom and Constraint in Adjudication: A Look Through the Lens of Cognitive Psychology, 67 BROOK. L. REV. 1097, 1113-14 (2002) (applying cognitive psychology experiments "to examine the process that governs mental tasks that require integrating multiple, ambiguous, and conflicting components into discrete choices," the mental process that judges apply in determining a legal controversy).

${ }^{153}$ For two compendia of the state of the art, neither of which include reference to international tribunals, see THE PSYCHOLOGY OF JUDICIAL DECISION MAKING (David E. Klein \& Gregory Mitchell eds., 2010); and Doron Teichman \& Eyal Zamir, Judicial DecisionMaking: A Behavioral Perspective, in THE OXFORD HANDBOOK OF BEHAVORIAL ECONOMICS AND THE LAW 664 (Eyal Zamir \& Doron Teichman eds., 2014).

${ }^{154}$ For a survey of the political science literature on international tribunals, see Mark A. Pollack, Political Science and International Adjudication, in THE OXFORD HANDBOOK OF INTERNATIONAL ADJUDiCATION 357, 361-69 (Cesare Pr. Romano, Karen J. Alter \& Yuval Shany eds., 2014). None of the literature includes applications of cognitive psychology to international judges.

${ }^{155}$ For a broad set of analyses of the WTO dispute settlement system, see generally THE WTO at Ten: The Contribution of the Dispute Settlement System (Giorgio Sacerdoti, Alan Yanovich \& Jan Bohanes eds., 2006).

${ }^{156}$ The condition of anonymity applies at both the panel and Appellate Body levels. See Understanding on Rules and Procedures, supra note 102, art. 14.3, art. 17.11. In passing, anonymity itself raises interesting behavioral hypotheses. On one hand, anonymity ostensibly protects dissenting panelists or Appellate Body members seeking reappointment from individual scrutiny by member states. For a discussion of the potential role of dissent in reappointment, see Manfred Elsig \& Mark A. Pollack, Agents, Trustees and International Courts: The Politics of Judicial Appointment at the World Trade Organization, 20 EUR. J. INT'L REL. 391, 406-07 (2014). On the other hand, anonymity reduces prestige payoffs associated with the signed separate opinion.

${ }^{157}$ Appellate Body Report, Working Procedures for Appellate Review, I 3.2, WT/AB/WP/6 (Aug. 16, 2010) (requiring the Appellate Body members to make every effort to take decisions by consensus).

${ }^{158}$ See Meredith Kolsky Lewis, The Lack of Dissent in WTO Dispute Settlement, 9 J. INT'L ECON. L. 895, 899 (2006) ("Since the WTO's inception, less than 6\% of panel reports and less
} 
The WTO is not unique in this respect. In some domestic judicial settings, even when judges are permitted to write separate opinions, they often refrain from doing so. The option to write a dissenting opinion may actually encourage "adversarial collaboration" on the bench, leading to a high proportion of unanimous opinions in some domestic courts. ${ }^{159}$ Members of the United States Supreme Court largely avoided writing individual opinions for over a century. ${ }^{160}$ Moreover, decisions of the Court of Justice of the European Union (CJEU) do not include dissents. ${ }^{161}$ However, the question of dissent is of particular importance in new tribunals-as most international courts are-as it interacts with the establishment of legitimacy in uncertain ways. ${ }^{162}$

Meredith Kolsky Lewis comprehensively canvassed many institutional and historical reasons explaining the lack of dissent in WTO rulings, while strongly arguing that an increase in dissenting opinions, certainly at the panel level, would have positive effects on the quality of decisions and the development of international trade law. ${ }^{163}$ She advocates removal of the formal preference for consensus and several additional steps that would encourage separate opinions. ${ }^{164}$

In contrast, James Flett has argued equally forcefully that panel dissents have not had any appreciable effect on decisional quality, that the "collective intelligence of reasonable judges should lead them to common ground," and that the overall collegiality of panels and the Appellate Body

than $2 \%$ of Appellate Body reports have included dissenting opinions."). It should be noted that the number of dissents has risen in recent years but largely due to a particular line of disputes regarding U.S. Department of Commerce practices of "zeroing" in dumping investigations.

${ }^{159}$ See Marsha S. Berzon, Dissent, "Dissentals," and Decision Making, 100 CALIF. L. REV. 1479, 1485-89 (2012) (discussing experience writing opinions as a federal judge on the Ninth Circuit Court of Appeals).

${ }^{160}$ See Stacia L. Haynie, Leadership and Consensus on the U.S. Supreme Court, 54 J. POL. 1158, 1159 fig.1 (1992) (depicting the spike in concurring and dissenting opinions that has occurred only recently at the Supreme Court).

${ }^{161}$ The practice of Advocate-General opinions preceding those of the CJEU allows for some diversity of reasoning. For discussion, see generally Josef Azizi, Unveiling the EU Courts' Internal Decision-Making Process: A Case for Dissenting Opinions?, 12 ERA F. 49 (2011).

${ }^{162}$ Speaking with one voice can bolster the position of a court; but enabling dissent projects diversity and signals confidence. For a discussion of this tension in the early years of the U.S. Supreme Court, see Meredith Kolsky, Justice William Johnson and the History of the Supreme Court Dissent, 83 GEO. L.J. 2069, 2070-82 (1995).

${ }^{163}$ See Lewis, supra note 158, at 917-19, 923 (arguing that WTO dissents can improve judicial decisions, serve as markers for future decisionmaking, and spur legislators to respond to problems with the law).

${ }^{164}$ See id. at 928 (concluding that dissents should no longer be discouraged by the WTO). 
should be preserved. ${ }^{165}$ Others have also praised the high degree of consensus in the Appellate Body in particular. ${ }^{166}$

This fascinating debate could benefit from behavioral insights, which it currently lacks. Notably, the existing debate relies neither on L\&E analysis nor on a particular formulation of rationality. Instead, it relies on differing interpretations of institutional settings and judicial outcomes. Behavioral questions arise nevertheless. Beyond the institutional and formal constraints on dissent, are there cognitive elements in judicial behavior at the WTO that limit dissent? And how might these factors influence the assessment of the quality of consensus decisions?

In the United States, ${ }^{167}$ there is a long tradition of theoretical and empirical examination of issues by collegial courts (i.e., courts that reach decisions as a group, with or without dissent ${ }^{168}$ ), as opposed to individual judges. ${ }^{169}$ The use of such multimember courts is justified by the notion that deliberation in a small, high-level group of jurists will help the court arrive at the correct decision. ${ }^{170}$ However, it creates strategic interactions between members of the court because no judge individually has the authority to determine the outcome. Judges in collegial courts inevitably must consider the views of their colleagues. These interactions are not only strategic, but also personal, entailing psychological elements, ${ }^{171}$ which open the door to cognitive and social psychology analysis. ${ }^{172}$

${ }^{165}$ James Flett, Collective Intelligence and the Possibility of Dissent: Anonymous Individual Opinions in WTO Jurisprudence, 13 J. INT'L ECON. L. 287, 287, 310 (2010).

${ }^{166}$ See Alberto Alvarez-Jimenez, The WTO Appellate Body's Decision-Making Process: A Perfect Model For International Adjudication?, 12 J. INT'L ECON. L. 289, 289 (2009) ("The functioning of the Appellate Body ( $\mathrm{AB}$ ) is virtually perfect in terms of collegial decision-making.").

${ }^{167}$ This is the case in other jurisdictions, including Canada. See Emmett Macfarlane, Essay, Consensus and Unanimity at the Supreme Court of Canada, 52 SUP. CT. L. REV. 379, 390-400 (2010).

${ }^{168}$ The terms "collegial" and "collegiality" in the WTO are usually used in the narrower sense, meaning all members of a panel or division of the Appellate Body agree to the same ruling.

${ }^{169}$ Much of this literature pursues or engages with the so-called attitudinal approach, which is primarily concerned with the influence of political or ideological attitudes of judges on their decisions, especially in the United States Supreme Court. For an analysis of the Supreme Court, see generally Jeffrey A. SEgal \& Harold J. Spaeth, The Supreme Court and the ATtiTUdinal Model REvisited (2002); and LEE EPSTEIN \& JACK KNIGHT, THE CHOICES JUSTICES MAKE (1998). For an analysis of the federal appellate courts, see generally VIRGINIA A. HETTINGER, STEFANIE A. LINDQUiST \& WENDY L. MARTINEK, JUDGING ON A COLLEGIAL COURT: INFLUENCES ON FEDERAL APPELLATE DECISION MAKING (2007).

${ }^{170}$ See Christopher R. Drahozal, Judicial Incentives and the Appeals Process, 51 SMU L. REV. 469, 469-70 (1998).

${ }^{171}$ See Wendy L. Martinek, Judges as Members of Small Groups ("[J]udges serving on appellate courts may squabble like children, bond like family, or behave toward one another in a more detached, professional manner, but both anecdotal and systematic evidence make clear that there is an affective component to the interactions between and among judges serving on appellate 
These studies indicate behavioral findings such as "panel effects,"173 polarization, and "groupthink"174 in which judges participating in a group decision concur with judicial outcomes that they would not have pronounced on their own-a behavioral phenomenon that can generally be referred to as "conformity effects." ${ }^{\text {"175 }}$ The group context of judicial decisionmaking can therefore influence judicial outcomes through cognitive channels, although the scope of this influence is still unclear.

Perhaps most troubling among the various conformity effects is the evidence from empirical research suggesting that the status of particular bench members can disproportionately influence the decisions of other members. Formal leadership (e.g., the position of chief justice or chair of a judicial division) as well as social leadership roles in courts can influence the independence of judicial colleagues' opinions, reducing the likelihood of dissent. ${ }^{176}$ This influence is only to be expected, and it casts doubts on the idea that a group of judges can better approximate the correct result. One recent study found that judges in criminal appeals in one domestic court were fifty percent more likely to vote for defendants when a particular justice did not preside than when he did. ${ }^{177}$ It should be emphasized that this study examined a court in which each sitting judge was obliged to determine his or her individual position on the verdict in the form of a vote; in other words, a separate opinion was mandatory (but without a

courts." (citation omitted)), in THE PSYCHOLOGY OF JUDICIAL DECISION MAKING, supra note 153 , at 73,75 .

${ }^{172}$ To be sure, this is another area where the lines between cognitive and sociological research tend to blur in terms of social psychology. As previously noted, Goodman and Jinks have written extensively on the pressures to conform in different international law contexts, with reference to cognitive effects. See supra note 42 and accompanying text.

${ }^{173}$ See, e.g. Pauline T. Kim, Deliberation and Strategy on the United States Courts of Appeals: An Empirical Exploration of Panel Effects, 157 U. PA. L. REV. 1319, 1329-31 (2009) (finding that the behavior of judges on a federal appeals panel is better explained as reflexive to the preferences of other members on the panel than as strategic to the possibility of being overruled on appeal).

${ }^{174}$ See, e.g., Melissa L. Breger, Making Waves or Keeping the Calm?: Analyzing the Institutional Culture of Family Courts Through the Lens of Social Psychology Groupthink Theory, 34 LAW \& PSYCHOL. REV. 55, 67-68 (2010) (arguing that "groupthink" negatively affects family court proceedings).

${ }^{175}$ See Martinek, supra note 171, at 82 ("[I]ndividuals participating in group decision making processes are susceptible to conformity effects....[M]embers of a group care about the evaluations of their fellow group members ....").

${ }^{176}$ See id. at 79 (describing the influence that formal leadership and characteristics such as collegiality or competence have on group decisionmaking); see also Haynie, supra note 16o, at 1166 (finding that the leadership of the Chief Justice of the Supreme Court affected the likelihood of coming to a consensus).

${ }^{177}$ Theodore Eisenberg, Talia Fisher \& Issi Rosen-Zvi, Group Decision Making on Appellate Panels: Presiding Justice and Opinion Justice Influence in the Israel Supreme Court, 19 PSYCHOL. PUB. POL'Y \& L. 282, 282 (2013). 
requirement of providing written reasons), not optional, ostensibly enhancing the possibility of dissent. ${ }^{178}$

Another strand of research looks at the conformity effects of seniority on the bench. "Freshmen" judges can be disproportionality deferential to incumbents because they desire socialization and acceptance. ${ }^{179}$ They might also be treated paternalistically by senior judges, ${ }^{180}$ reducing their options for independent impact, even when the possibility of dissent exists.

On this backdrop, we might ask, to what extent do leading WTO dispute settlement roles, such as panel chairs, or Appellate Body chairpersons, dominate the reports issued under consensus? Do they squelch dissent, as Lewis argues? Or are there dominant personalities in the panels and the Appellate Body that exercise social leadership, promoting collegiality but preventing the development of diverse and perhaps progressive or otherwise innovative solutions to problems in WTO law? Are "newbie" panelists or even Appellate Body members (many of whom arrive in Geneva with a wealth of prior professional experience, sometimes as arbitrators) sociologically and psychologically deterred from taking independent positions, let alone expressing them in dissenting or concurring opinions? Evidence substantiating the hypotheses on undesirable conformity effects could agitate in favor of the concern voiced by Lewis.

It would be methodologically challenging to systematically collect such evidence. Qualitative empirical research based on semi-structured interviews of panelists, Appellate Body members, and attorneys and staff of the WTO secretariat would be one avenue, ${ }^{181}$ although constraints of confidentiality might restrict the knowledge gained to the level of anecdotal evidence, which to some extent already circulates among cognoscenti. There are other methods, however. Conformity effects in WTO dispute settlementspecifically, the relative weight of panel chairs in determining outcomes-can

\footnotetext{
${ }^{178} \mathrm{Id}$. at 286.

${ }^{179}$ See Virginia A. Hettinger, Stefanie A. Lindquist \& Wendy L. Martinek, Acclimation Effects and Separate Opinion Writing in the U.S. Courts of Appeals, 84 SOC. SCI. Q. 792, 802 (2003) (exploring the "freshman effect" on separate opinion authorship).

${ }^{180}$ Cf. Saul Brenner \& Timothy M. Hagle, Opinion Writing and Acclimation Effect, 18 POL. BEHAV. 235, 252-53 (1996) (explaining the decrease in the number of opinions written by Justice Rehnquist when he was elevated from Associate Justice to Chief Justice).

${ }^{181}$ On conducting such interviews with elite groups in political circumstances, see Joel D. Aberbach \& Bert A. Rockman, Conducting and Coding Elite Interviews, 35 PS: POL. SCI. \& POL. 673, 674-75 (2002). For a recent study in an international relations context addressing the possibility of expert rationality as well as the problem of overconfidence biases, see Emilie M. Hafner-Burton, D. Alex Hughes \& David G. Victor, The Cognitive Revolution and the Political Psychology of Elite Decision Making, 11 PERSP. ON POL. 368, 370-78 (2013).
} 
in fact be gleaned from existing quantitative research that has been conducted with respect to another long-standing debate in international judicial design: whether rulings rendered by adjudicators appointed ad hoc are of lower quality than those by permanent or standing judiciaries. As already noted, WTO panelists are appointed ad hoc, while appeals are made to the standing Appellate Body. Proposals have been made to create a permanent panel body in the WTO. ${ }^{182}$ Proponents of such a standing body often claim that permanent arbitrators or panelists, as the case may be, will improve the quality of decisions because they will gain experience by virtue of their permanent status. ${ }^{183}$ Thus, it has been argued that more experienced panelists will yield higher quality panel decisions, as indicated by a reduced rate of reversals made by the Appellate Body. ${ }^{184}$ Yet in a quantitative study, Marc Busch and Krzysztof Pelc have shown that the experience of panelists, in general, has no statistical effect on the likelihood of panel rulings being reversed. ${ }^{185}$ However, when the panel chairs are experienced, rulings are far less likely to be reversed by the WTO Appellate Body. ${ }^{186}$ This strongly suggests that panel chairs have a disproportionate role in panel outcomes (although no similar indications exist with respect to the Appellate Body). It also shows a high degree of acculturation to the system over time.

To be sure, this additional, empirically based knowledge does not resolve the normative debate regarding the lack of dissent in the WTO. Indeed, those opposed to increased expressions of dissent would argue that it merely emphasizes the importance of consensus gathered around experienced chairs who can promote the quality of panel rulings. There is no need, however, to take a position on this question here. For present purposes, the hypotheses raised by behavioral research on courts as small decisionmaking groups are clearly relevant to international tribunals, in this case demonstrating the effects of cognitive elements on judicial dissent in the WTO, with implications for the quality of judicial decisions.

${ }^{182}$ See generally William J. Davey, The Case for a WTO Permanent Panel Body, 6 J. INT'L ECON. L. 177 (2003) (exploring the case for and against a permanent WTO panel body).

${ }^{183}$ See, e.g., id. at 179-80 ("A permanent panel body would ensure a greater level of expertise since its members would over time serve on many panels and thus be better able to deal with the increased complexity of WTO dispute settlement.").

${ }^{184}$ Special Session of the Dispute Settlement Body, Contribution of the European Communities and Its Member States to the Improvement of the WTO Dispute Settlement Understanding, TN/DS/W/1, at 2 (Mar. 13, 2002) (suggesting that permanent panels would result in fewer reversals, thereby reducing time, workload, and costs).

${ }^{185}$ Marc L. Busch \& Krzysztof J. Pelc, Does the WTO Need a Permanent Body of Panelists?, 12 J. INT'L ECON. L. 579, 591 (2009).

${ }^{186} \mathrm{Id}$. at $591-92$. 


\section{The Individual: Target Selection, Framing Effects, and Preference Reversals in International Humanitarian Law}

International humanitarian law (IHL) - the "jus in bello"-is a branch of public international law that imposes significant restrictions on the use of violence by military forces during international (and noninternational) armed conflict, through a mix of treaty and custom. ${ }^{187}$ Among IHL's most fundamental elements are the complementary principles of military necessity and proportionality. ${ }^{188}$ Both of these principles require military commanders (acting individually or in very small decisionmaking groups or "cells," as is often the case in practice) ${ }^{189}$ to make judgment calls, either in the heat of battle or in more deliberate, strategic settings. Such targeting decisions involve a combination of operational and legal factors that amount to a kind of cost-benefit analysis necessarily performed under conditions of uncertainty-the Clausewitzian fog of battle ${ }^{190}$-and therefore provide an exceptionally appropriate area for research involving legal standards, cognitive psychology of individuals, and empirical, even experimental, research.

Under the IHL principle of military necessity, attacks must be directed at military objectives (i.e., objectives that cumulatively make an effective contribution to the adversary's military action and whose destruction or neutralization offers a definite military advantage). ${ }^{191}$ Under the IHL principle of proportionality, it is recognized that an attack against a military objective may cause "incidental loss of civilian life, injury to civilians, damage to civilian objects, or a combination thereof," but this damage must

${ }^{187}$ See generally THE HANDBOOK OF INTERNATIONAL HUMANITARIAN LAW (Dieter Fleck ed., $2 \mathrm{~d}$ ed. 2008) (describing the development and application of international humanitarian law).

${ }^{188}$ See LAURIE R. BLANK \& GREgORY P. NOONE, INTERNATIONAL LAW AND ARMED CONFLICT: FUNDAMENTAL PRINCIPLES AND CONTEMPORARY CHALLENGES IN THE LAW OF WAR 36-40, 51-53 (2013).

${ }^{189}$ See, e.g., Tony Montgomery, Legal Perspective from the EUCOM Targeting Cell, 78 INT'L L. STUD. 189, 190-95 (2002), available at http://www.au.af.mil/au/awc/awcgate/navy/kosovo_legal.pdf (describing the process used to determine military targets).

${ }^{190}$ See John Ferris \& Michael I. Handel, Clausewitz, Intelligence, Uncertainty and the Art of Command in Military Operations, 10 INTELLIGENCE \& NAT'L SECURITY 1, 1-2 (1995) (describing the "inability to collect accurate, relevant and complete data about the battlefield, and on one's own forces no less than on the enemy").

${ }^{191}$ See Michael N. Schmitt, Military Necessity and Humanity in International Humanitarian Law: Preserving the Delicate Balance, 50 VA. J. INT'L L. 795, 798-805 (2010) (describing the balance between military necessity and respect for humanity and the codification of international humanitarian law). The principle has deep historical roots. See Burrus M. Carnahan, Lincoln, Lieber and the Laws of War: The Origins and Limits of the Principle of Military Necessity, 92 AM. J. INT'L L. 213, 215 (1998) (describing the historical origins of the military necessity principle). 
not be "excessive in relation to the concrete and direct military advantage anticipated."

In other words, under IHL, military commanders must assess the potential for a military advantage proffered by a contemplated attack on a military target and balance this advantage against the possible harm to civilian objects (often referred to as "collateral damage"). Not surprisingly, however, the assessment of both sides of this equation is rife with speculation and subjectivity. ${ }^{193}$ Moreover, the content of these tests remains vague and problematic in its application, both ex ante and ex post, for example in the context of "targeted killings" ${ }^{\text {"194 }}$ and drone attacks ${ }^{195}$ or the choice between aerial attacks of different types (e.g., "precision" versus "area" bombings) $)^{196}$ or the option of more accurate-but more dangerousmethods of ground incursions (e.g., "boots on the ground").

This vagueness has led some jurists to establish the notion of the "reasonable military commander" as a normative benchmark that can be seen as an objective-perhaps minimum-standard of conduct with respect to operative decisions such as targeting. A committee established to advise the Prosecutor of the International Criminal Tribunal for the Former Yugoslavia (ICTY) regarding the legal aspects of NATO attacks in Kosovo in the late $1990 \mathrm{~s}^{197}$ had this to say on the applicable legal standard:

${ }^{192}$ Protocol I, supra note 145 , art. 51.5(b). The Protocol is not conventionally binding upon all states, but these provisions can be taken, at least for present purposes, to be a concise formulation of the principle of proportionality in customary international law.

${ }^{193}$ There are models for estimating collateral damage that are employed at some levels. See, e.g., Steven C. Gordon \& Douglas D. Martin, Modeling and Simulation for Collateral Damage Estimation in Combat, 5805 PROC. SPIE 309, 309 (2005), available at http://proceedings.spiedigitallibrary.org/ proceeding.aspx?articleid $=864347$ (describing how modeling is used to minimize predicted collateral damage in a combat situation); Jeffrey H. Grotte, $A$ Targeting Model that Minimizes Collateral Damage, 25 NAVAL RES. LOGISTICS Q. 315, 315-16 (1978) (describing a mathematical model which prescribes the minimum and maximum amounts of damage allowed).

${ }^{194}$ See Amichai Cohen \& Yuval Shany, A Development of Modest Proportions: The Application of the Principle of Proportionality in the Targeted Killings Case, 5 J. INT'L CRIM. JUST. 310, 313-18 (2007) (exploring the application of international humanitarian law-the principle of proportionality - to military operations involving targeted killing).

${ }^{195}$ The literature on drone warfare has grown exponentially over the last few years. See, e.g., Chris Jenks, Law from Above: Unmanned Aerial Systems, Use of Force, and the Law of Armed Conflict, 85 N.D. L. REV. 649, 656-65 (2009) (analyzing the legality of drone strikes).

${ }^{196}$ For an account of this historical problem, see generally W. Hays Parks, 'Precision' and 'Area' Bombing: Who Did Which, and When?, 18 J. STRATEGIC STUD. 145 (1995).

${ }^{197}$ For accounts of the central issues, see generally W.J. Fenrick, Targeting and Proportionality During the NATO Bombing Campaign Against Yugoslavia, 12 EUR. J. INT'L L. 489 (2001); and Daniel H. Joyner, The Kosovo Intervention: Legal Analysis and a More Persuasive Paradigm, ${ }_{13}$ EUR. J. INT'L L. 597 (2002). 
The answers to these questions are not simple. It may be necessary to resolve them on a case by case basis, and the answers may differ depending on the background and values of the decision maker. It is unlikely that a human rights lawyer and an experienced combat commander would assign the same relative values to military advantage and to injury to noncombatants. Further, it is unlikely that military commanders with different doctrinal backgrounds and differing degrees of combat experience or national military histories would always agree in close cases. It is suggested that the determination of relative values must be that of the "reasonable military commander". Although there will be room for argument in close cases, there will be many cases where reasonable military commanders will agree that the injury to noncombatants or the damage to civilian objects was clearly disproportionate to the military advantage gained. ${ }^{198}$

In many contexts, such a standard of reasonableness would be viewed as a legal fiction of sorts, or as an aspirational, normative test. ${ }^{199}$ By employing theories and methodologies from behavioral economics, applied to the relevant decisionmakers-military commanders, whose actions are attributable to states and, in certain circumstances, might bear international criminal responsibility for their own decisions-it should be possible to grant the reasonableness standard real meaning. This could enable us to draw the contours of an answer to what is essentially an empirical question with normative implications: who is the reasonable military commander?

Interesting hypotheses in this respect arise from the study of cognitive framing effects that occur when alternative descriptions of the same decision problem give rise to different preferences. ${ }^{200}$ Experimental research on the psychology of risk-related decisionmaking has shown that individual decisionmakers' preferences can shift when the same problem is framed in different ways. In the most foundational experimental proof of this behavioral bias, Tversky and Kahneman showed that subjects made different choices when the outcomes of their decisions were depicted as losses rather than gains (conforming to general Prospect Theory), even though they were essentially identical. ${ }^{201}$ The original Tversky and

\footnotetext{
${ }^{198}$ FinAL REPORT TO THE PROSECUTOR BY THE COMMITTEE ESTABLISHED TO REVIEW THE NATO Bombing CAMPAign Against the FEDERAL REPUblic OF YugosLaVia II 50 (2000), available at $\mathrm{http}: / / \mathrm{www} . i c t y . o r g / s i d / 10052$.

${ }^{199}$ See Mayo Moran, The Reasonable Person: A Conceptual Biography in Comparative Perspective, 14 LEWIS \& CLARK L. REV. 1233, 1237-38 (2010) (describing American private and public law approaches to determining what constitutes a reasonable person).

${ }^{200}$ See supra note 57 (discussing framing effects).

${ }^{201}$ Tversky \& Kahneman, supra note 57 , at 453 .
} 
Kahneman experiment related to expenditure on health measures in the face of a deadly epidemic disease. ${ }^{202}$ It is not difficult to tweak this experiment to address military necessity and collateral damage. Might military commanders be susceptible to the same distortions of rationality? And if so, what are the implications for international law? Should the standard of "reasonable military commander" relating to proportionality in targeting decisions take into account the ways in which reasonableness diverges from perfect rationality?

Consider, for example, the following general design of an experiment, closely following the Tversky and Kahneman framework. Two groups of subjects would be presented with the following hypothetical:

Imagine that the enemy has stockpiled a significant quantity of strategic munitions in the basement of an apartment building that normally houses 200 civilians. As part of a military operation your unit has been assigned the mission of eliminating this stockpile. You have two alternative plans of action to choose from, both of which will eliminate the munitions.

A first group of subjects would be posed with this question:

If plan A-a manned aerial attack-is adopted, 8o civilians will survive. If plan $\mathrm{B}$-an unmanned drone attack-is adopted, there is $1 / 3$ probability that all civilians will survive, and $2 / 3$ probability that no civilians will survive.

A second group of subjects would be posed with what is in essence the same scenario, but framed differently:

If plan A-a manned aerial attack-is adopted, 120 civilians will die. If plan $\mathrm{B}$-an unmanned drone attack-is adopted, there is $2 / 3$ probability that all civilians will die, and $1 / 3$ probability that no civilians will die.

If the differential framing has the same effect in this IHL context as it has elsewhere, we might hypothesize that the first group will prefer plan A, whereas the second group will prefer plan B. An outcome like this would be significant not only in the construction of the "reasonable military commander" as a bounded rational actor, but could also contribute to the design of military manuals. For example, the wording of guidelines matters not only for interpretation but also for cognition. Moreover, an experiment like this could test whether military commanders with different levels of 
experience and training have developed rationality that overcomes the "trick" of framing effects by using different groups from among military commanders and civilians as subjects. This is only an indicative experiment. ${ }^{203}$ Many others could be constructed to test the rationality of military commanders in different circumstances and in comparison with other groups. Consider the following: subjects (playing the role of military commanders or simply representatives of the general public) are presented with two risky military operations. In scenario A, there is a $9 / 10$ chance of achieving a small military gain (1, on a scale of 1 to 10 representing the absolute magnitude of a military gain), and a $1 / 10$ chance of achieving nothing from the operation. In scenario $B$, there is a $1 / 10$ chance of gaining a very significant military advantage (10 on the same scale) and a $1 / 10$ chance of gaining nothing. Subjects would then be asked (a) which alternative they would approve and (b) how much collateral damage would be justified in each option (i.e., the "price" of the operation, which can, under terms of proportionality, serve as a proxy for the expected military advantage, all things considered). Similarly constructed experiments have exposed the cognitive phenomenon of preference reversals: people may prefer gamble A but place a higher price tag on gamble B. ${ }^{204}$ Which of these calculi should be adopted as representative of a "reasonable military commander?" Perhaps military commanders are less prone to this cognitive weakness in rationality?

Another issue begging for behavioral analysis is the question of force protection: to what extent should military forces take risks to prevent civilian harm? And is the reduction of risk to one's own forces a legitimate factor in potentially increasing risk to civilians as part of the proportionality calculus? ${ }^{205}$ The normative issues involved are absorbing,

${ }^{203}$ I highlight here the advantages of experimental research, but this does not in any way reduce the importance of field-based empirical research on similar topics. See, e.g., Fellmeth, supra note 6, at 133-34 (describing an empirical methodology to study military planning's relationship with the proportionality principle, the minimization of the ratio of civilian to combatant causalities inflicted in conflicts). Moreover, experimental research and field studies can be mutually reinforcing, overcoming each other's weaknesses.

${ }^{204}$ See David M. Grether \& Charles R. Plott, Economic Theory of Choice and the Preference Reversal Phenomenon, 69 AM. ECON. REV. 623, 623 (1979) (describing an experiment showing that although test subjects preferred one lottery over another, they tended to place a higher value on the other, non-preferred lottery which had higher potential payouts but lower winning probability than the preferred lottery); see also Sarah Lichtenstein \& Paul Slovic, Introduction to THE COnStRUCtion OF PREFERENCE 1, 20-22 (Sarah Lichtenstein \& Paul Slovic eds., 2006) (providing an overview of various theories and explanations for preference reversal).

${ }^{205}$ See, e.g., David Luban, Risk Taking and Force Protection (describing various approaches by philosophers in evaluating the morality of increasing risk to civilians in order to reduce risk to military forces), in READING WALZER 277, 287-90 (Yitzhak Benbaji \& Naomi Sussman eds., 2014). 
but no less intriguing would be a study from which we might gain an understanding of how force protection factors into decisionmaking. In the preference reversal example just discussed, we could, for example, replace collateral damage with own-costs. But experiments taking into account all three factors-military advantage, collateral damage, and own losses in combat-could be designed. Thus, an experiment with relevant subjects might pose the following question:

You are assessing the proportionality of an attack against key enemy personnel. You may choose between two modes of attack: Option A - aerial attack; and Option B - ground troop attack.

A first group would be given the following alternative outcomes (the numbers expressing relative results on a scale of 1 to 10 reflecting the severity of collateral damage and the military gain, respectively):

Option A - Civilians killed: 6; Military advantage: 7

Option B - Civilians killed: 2; Military advantage: 10

A second group would be fed the following information:

Option A - Civilians killed: 6; Military advantage: 7;

Soldiers killed: 10

Option B - Civilians killed: 2; Military advantage: 10; Soldiers killed: 4

And, finally, a third group would be presented with these options:

Option A - Civilians killed: 6; Military advantage: 7;

Soldiers killed: 4

Option B - Civilians killed: 2; Military advantage: 10;

Soldiers killed: 10

Here, the hypothesis, or rather, the examined element of bounded rationality, would also be one of preference reversals. The relative evaluation of two different alternatives is affected by an exogenous factor. Note that all three groups are faced with the same outcomes in the strictest terms of proportionality: the number of civilians killed compared to the military advantage gained (i.e., without taking into account force protection considerations). The only difference between the three groups is the degree of harm caused to own forces. The first group has no data on this, the second group faces moderate damage, and the third a very high degree of harm. Moreover, Option B is clearly superior to Option A for all groups in terms of proportionality. Nevertheless, one might hypothesize that subjects in the third group would be put off by the high number of own casualties in 
Option B, preferring Option A and in essence reversing the preference. At the very least, this would show us that force protection is de facto taken into account as part of the proportionality calculus, with or without legal basis. In short, it appears that behavioral and experimental analysis has great potential to inform international humanitarian law, as well as other areas of international law in which individuals are key decisionmakers, such as international economic law and human rights.

\section{CONCLUSION}

The incorporation of insights from cognitive psychology and behavioral economics into the study of international law is a difficult but necessary next step in the evolution of a legal discipline. International law has, over the last two decades, engaged with the ever-increasing complexity and sophistication of other academic fields such as political science and economics. This Article has endeavored to set out a general yet comprehensive and systematic framework for taking that step, an intellectual invitation to add behavioral analysis to the international legal researcher's toolbox.

We have seen that there are methodological challenges involved, as a matter of course. Behavioral economics focuses on individual behavior, whereas international law is the domain of states, peoples, organizations, and other collectives, in addition to individuals. Behavioral economics is a field immersed in experimental and empirical research, which can be difficult, but very rewarding, to replicate in the international arena. Behavioral analysis also lacks the neat parsimony of traditional rational choice theorizing, which has gained a following among international legal researchers. These challenges are not, however, weaknesses, but rather strengths, as we struggle to better understand how international law works and how it interacts with human behavior in different settings and environments. As the examples in Part IV illustrate, there is much to study through behavioral analysis at the state, group, and individual levels. Theoretical applications, field studies, and experimental research are all methodologies that can be brought to bear on behavioral international law, in practically all subfields. Indeed, those examples-analysis of treaty development, the role of dissent in international tribunals, and cognitive biases in target selection in armed conflict-were of an almost minimal nature. The menu of possible research avenues is huge, as is the potential for gaining a richness and depth that currently only exists in a small, but promising segment of empirical work relating to international law. Areas of general concern-such as sources of international law, state responsibility, 
and enforcement-as well as a host of specialized issues-from the structure of concessions in international agreements on trade in services to derogations in human rights treaties-beckon for empirically grounded behavioral research. Indeed, empiricism could benefit any area of international law in which individual decisionmaking comes into play.

The challenge now is to design and execute rigorous empirical research programs that can illuminate behavioral deviations from rationality in decisionmaking that bear upon international legal problems, ideally through intensive collaborations between researchers and scholars with complementary training. However, as much as there is room for enthusiasm toward the advent of behavioral international law, there is also a crucial need to exercise caution and avoid any sweeping claims about international law. To avoid the difficulties in gaining acceptance and legitimacy that other theoretical approaches to international law (such as rational choice) have faced, a behavioral approach to international law must be pursued with both methodological meticulousness and intellectual humility. 